\title{
Evaluation of Salvage Logging Productivity and Costs in Windthrown Norway Spruce-Dominated Forests
}

\author{
Kalle Kärhä 1,*(D), Tuomas Anttonen ${ }^{2}$, Asko Poikela ${ }^{3}$, Teijo Palander ${ }^{2}$, Ari Laurén ${ }^{2}$ (D), \\ Heli Peltola ${ }^{2}$ (i) and Yrjö Nuutinen ${ }^{4}$ \\ 1 Stora Enso Wood Supply Finland, P.O. Box 309, FI-00101 Helsinki, Finland \\ 2 School of Forest Sciences, University of Eastern Finland, P.O. Box 111, FI-80101 Joensuu, Finland; \\ tuomas875@gmail.com (T.A.); teijo.s.palander@uef.fi (T.P.); ari.lauren@uef.fi (A.L.); heli.peltola@uef.fi (H.P.) \\ 3 Metsäteho Ltd, Vernissakatu 1, FI-01300 Vantaa, Finland; asko.poikela@metsateho.fi \\ 4 Natural Resources Institute Finland, P.O. Box 68, FI-80101 Joensuu, Finland; yrjo.nuutinen@luke.fi \\ * Correspondence: kalle.karha@storaenso.com; Tel.: +358-40-519-6535
}

Received: 25 March 2018; Accepted: 18 May 2018; Published: 22 May 2018

\begin{abstract}
Different abiotic and biotic disturbances are expected to become more common in the future due to a warming climate. Globally, post-disturbance salvage logging is becoming more predominant to recover economic value from timber in disturbed forests. This study collected comparative time-study data and analyzed the productivity of cutting for windfalls in clear cuttings and determined the cutting costs of windfalls. Furthermore, the logging (i.e., cutting and forwarding) costs of wind-damaged trees and those of undamaged standing Norway spruce (Picea abies (L.) Karst.) trees in clear cuts were calculated in Finland. The results revealed that the cutting productivity of windfalls was 19-33\% lower than that of undamaged stems. The cutting costs of windthrown stems with a volume of $0.3-1.5 \mathrm{~m}^{3}$ were $35-64 \%$ higher and the logging costs of windfalls were $10-30 \%$ higher than those of undamaged standing stems. The study provided new understanding regarding the productivity and costs of salvage logging operations under Finnish conditions. Even if the logging of windfalls is expensive and laborious, salvage logging operations are important for forest stands and their health to minimize post-disaster damage outbreaks in coniferous forests, such as the damage caused by bark beetles-mainly Ips typographus $\mathrm{L}$.
\end{abstract}

Keywords: windstorm; windfall; post-disturbance; forest health; forest management; changing climate; Ips typographus; wood harvesting; clear cutting; boreal forests

\section{Introduction}

Forest disturbances have caused noticeable damage to European forests over the last few decades [1-3]. For example, during the period of 1950-2000, an average of 35 million $\mathrm{m}^{3}$ of wood was damaged annually by different abiotic and biotic disturbances, corresponding to $8.1 \%$ of the total annual cuttings in Europe and $0.15 \%$ of the total volume of growing stock during this time period $[1,4]$. As a single damaging agent, windstorms caused 53\% of the total damage from 1950-2000. Various biotic factors caused $16 \%$ of the damage, similar to the amount of damage caused by forest fires. As a single biotic factor, bark beetles-mainly Ips typographus L.—caused $50 \%$ of all biotic damage [1,4].

So far, western and central Europe have suffered the most wind damage since the 1990s as a result of very destructive winter storms like Vivian in 1990 and Lothar and Martin in 1999 [5]. Wind storms have also been increasing in northern Europe; for example, in January of 2005, the Gudrun storm damaged more than 70 million $\mathrm{m}^{3}$ of timber in southern Sweden [6]. In January of 2007, the Kyrill storm damaged 54 million $\mathrm{m}^{3}$ of timber in central Europe and the storm known as Per damaged 12 million $\mathrm{m}^{3}$ of timber, mainly in Sweden [5]. Windstorms have also caused destructive wind damage 
to Finnish forests. For instance, in late autumn of 2001, the storms Pyry (1 November) and Janika (15 November) damaged 7.3 million $\mathrm{m}^{3}$ of timber in Finland [7]. In summer of 2010 the Asta (29 July), Veera (4 August), Lahja (7 August) and Sylvi (8 August) storms damaged 8.1 million $\mathrm{m}^{3}$ of timber [8]. The Tapani (26 December) and Hannu (27 December) storms damaged 3.5 million $\mathrm{m}^{3}$ of timber in the late autumn of 2011. Recently, in the late autumn of 2013, the Eino (17 November), Oskari (1 December) and Seija (12 December) storms damaged 3.0 million $\mathrm{m}^{3}$ of timber in Finland [9]. In total, over 25 million $\mathrm{m}^{3}$ of timber has been damaged in Finland during storms since $2000[10,11]$.

According to some recent studies, windstorm frequency and severity may increase due to a changing climate in northern Europe, including in Scandinavia (e.g., [2,12-15]), whereas based on some other studies, this prediction is not supported (e.g., $[16,17])$. However, the risk of wind damage to forests may still increase even if the frequency and severity of wind storms do not increase. This is due to the shortening of the frozen soil period, which currently improves tree anchorage during the windiest season of the year from late autumn to early spring [18-21]. Moreover, storms may be accompanied by heavier rainfall, leading to more saturated soils and increased risk of wind damage [22]. At the same time, the increase in growing stock and share of older forests may further increase the vulnerability of forests to damage $[1,2,23,24]$.

As a result of devastating wind storms, the amount of deadwood in forests can be expected to increase, despite logging (i.e., cutting and forwarding) operations. Leaving the damaged trees in the forest may offer a cost-efficient means to increase forest biodiversity because of the lower market value of damaged trees [25]. However, despite potential negative effects on biodiversity and other forest values [25,26], salvage logging is often conducted (e.g., [4,27-38]), even in areas otherwise excluded from logging and reserved for nature conservation (cf. [39,40]). This is carried out because post-disturbance salvage logging helps to recover economic value from timber in disturbed forests (e.g., $[26,41])$ and also helps to avoid consequent damage outbreaks, likely caused by spruce bark beetles (e.g., [42-48]). On the other hand, according to Havašová et al. [40], sanitation felling (i.e., removal of standing beetle-infested trees) only marginally reduces beetle populations in comparison with salvage cutting.

In Finland, the Forest Damage Prevention Act [49] requires a forest landowner to harvest windfalls from the forest stand if the amount of damage may otherwise cause consequential damages to forests, for example, due to bark beetles. According to the Forest Damage Prevention Act, the forest owner should remove from the stand any trees past the seedling stage exceeding 10 and $20 \mathrm{~m}^{3} \mathrm{ha}^{-1}$ of damaged timber (with a stump diameter $\left(\mathrm{d}_{0}\right)>10 \mathrm{~cm}$ ) in Norway spruce (Picea abies (L.) Karst.) and Scots pine (Pinus sylvestris L.) forests, respectively. Because different abiotic and biotic disturbances are increasing under a changing climate, it is important to develop resource-efficient salvage cutting approaches. This is because salvaging wind-damaged (uprooted and broken) trees is much more difficult and expensive than logging undamaged standing trees. Forest machine contractors in Finland have also emphasized that the logging costs of wind-damaged trees are typically 30-70\% higher than those of undamaged tree stems [50]. According to the survey of the Trade Association of Finnish Forestry and Earth Moving Contractors, the most commonly used payment method for wind damage salvaging for a forest machine contractor is to add a so-called additional 'wind damage charge' to the normal logging fee. For example, Jaakkola [51] reported that in 2012 the average additional wind damage charge percentage in Finland was around 37\%.

Many previous studies on productivity and the costs of salvage logging have been conducted in different countries after destructive wind storms (cf. [4,27-38]). In this work, we evaluated, for the first time in Finland, the productivity and costs of salvage logging after disastrous windstorms. More specifically, we: (i) analyzed the distributions of effective time consumption and stem processing in salvage cutting; (ii) modelled both stem processing and moving times in salvage cutting operations; (iii) clarified the average amount of miscellaneous time spent in salvage cutting; (iv) determined the productivity of salvage cutting; and (v) calculated the salvage cutting and logging costs in windstorm 
stands. In this study, salvage logging of wind-damaged trees, as well as the logging of undamaged standing trees in clear cuts, was investigated.

\section{Materials and Methods}

\subsection{Collecting Time-Study Data}

The time-study data were collected in eastern Finland in December 2013 after the Eino and Seija windstorms. There were three single-grip harvesters (Ponsse Ergo (by Ponsse Plc, Vieremä, Finland), John Deere 1270D ECOIII (by John Deere Forestry Ltd, Joensuu, Finland), and Logset 8H GT (by Logset Ltd, Mustasaari, Finland)) as well as three harvester operators used in the study (Table 1). The same harvesters/operators that cut the damaged trees also felled the undamaged standing trees of the clear cuts. All operators were skilled at final fellings, with more than 10 years of work experience. Each operator had also cut a lot of windfalls after the Asta windstorm in 2010. Hence, the study was considered a comparative time study (cf. [52,53]).

Table 1. The main technical specifications of the study's single-grip harvesters.

\begin{tabular}{|c|c|c|c|}
\hline Property & Ponsse Ergo & John Deere 1270D ECOIII & Logset 8H GT \\
\hline Weight $(\mathrm{kg})^{1}$ & 19,000 & 20,000 & 21,000 \\
\hline Engine & Mercedes-Benz OM 906 LA & John Deere 6090 PowerTech Plus & Sisu 74 AWI \\
\hline Power $(\mathrm{kW})$ & 205 & 160 & 205 \\
\hline Boom & Ponsse HN125 & TJ 210 H97 & Mesera 240 \\
\hline Maximum reach $(\mathrm{m})$ & 10 & 9.7 & 10.3 \\
\hline Lifting capacity gross (kNm) & 190 & 178 & 240 \\
\hline Harvester head & Ponsse H73 & John Deere H414 & Logset TH 75X \\
\hline Weight $(\mathrm{kg})$ & 1100 & 1100 & 1300 \\
\hline Felling diameter $(\mathrm{cm})$ & 72 & 62 & 75 \\
\hline Delimbing diameter $(\mathrm{cm})$ & 70 & 43 & 68 \\
\hline
\end{tabular}

Note: ${ }^{1}$ In work weight equipped with tracks and chains in the study.

Our study consisted of nine stands with the total area of 3.44 hectares. They are located in Pieksämäki (Stand 1: $62^{\circ} 16^{\prime} \mathrm{N}, 27^{\circ} 22^{\prime} \mathrm{E}$ in WGS84; Stand 2: $62^{\circ} 16^{\prime} \mathrm{N}, 27^{\circ} 5^{\prime} \mathrm{E}$ ), Rantasalmi (Stand 3: $62^{\circ} 3^{\prime} \mathrm{N}, 28^{\circ} 2^{\prime} \mathrm{E}$; Stand 4: $61^{\circ} 56^{\prime} \mathrm{N}, 28^{\circ} 22^{\prime} \mathrm{E}$; Stand 5: $61^{\circ} 57^{\prime} \mathrm{N}, 28^{\circ} 21^{\prime} \mathrm{E}$; Stand 6: $61^{\circ} 59^{\prime} \mathrm{N}, 28^{\circ} 28^{\prime} \mathrm{E}$; Stand 7: $61^{\circ} 59^{\prime} \mathrm{N}, 28^{\circ} 25^{\prime} \mathrm{E}$ ), Parikkala (Stand 8: $61^{\circ} 31^{\prime} \mathrm{N}, 29^{\circ} 28^{\prime} \mathrm{E}$ ) and Savonlinna (Stand 9: $61^{\circ} 48^{\prime} \mathrm{N}$, $29^{\circ} 10^{\prime} \mathrm{E}$ ). The stands were divided into 15 time-study plots according to cutting type (windfall vs. normal standing tree cutting). There were nine time-study plots of windfalls and six study plots of undamaged standing trees in the study. The harvester production data with stem-specific information (i.e., stm files [54]) were captured from each study plot.

The cutting work was recorded on video using a Sony HDR-CX220E digital HD video camera recorder (by Sony Corporation, Tokyo, Japan), and the time and motion study was carried out by analyzing the video material using a tool developed by one of the co-authors (Ari Laurén) (cf. [55]). The tool was developed using Microsoft Visual Basic language in the Microsoft Excel software. Using the analysis tool, a video clip was browsed in an Excel sheet and the work element boundaries were determined by the researcher during browsing. By using the time signature in the video clip, the start and end times of each work element were recorded together with the code of the work element. The video clip could be viewed quickly, forwarded and rewound, or viewed in slow motion when needed. The accuracy was one second (s) of the time of the recording.

The data included 1529 wind-damaged and undamaged standing stems, equivalent to $1161.0 \mathrm{~m}^{3}$ solid over the bark (henceforth referred to only as $\mathrm{m}^{3}$ ). The average stem volume of removal was $0.76 \mathrm{~m}^{3}$. From the windfall study plots, a total of 938 stems were cut (average stem volume of removal: $0.70 \mathrm{~m}^{3}$ ) and from the undamaged standing tree study plots, a total of 591 stems were felled (average stem volume of removal: $\left.0.85 \mathrm{~m}^{3}\right)$. The majority $(80 \%)$ of the stems that were processed were Norway spruce; $16 \%$ of the harvested stems were Scots pine, and $4 \%$ of the stems were birch (Betula spp. L.). 
The log sections of the coniferous stems were cross-cut log assortments that were processed as accurately as possible while avoiding bucking a downgraded (e.g., cracked) log for the sawmills (cf. [56,57]). The spruce and pine logs were mostly $3.7-5.5 \mathrm{~m}$ long with increments of $0.3 \mathrm{~m}$. The minimum top diameter of the spruce logs was $16 \mathrm{~cm}$, and the minimum top diameter of the pine logs was $15 \mathrm{~cm}$. The lengths of spruce and pine pulpwood were $2.7-4.5 \mathrm{~m}$ and $2.7-5.1 \mathrm{~m}$, respectively. The target length for the pine pulpwood was $5.0 \mathrm{~m}$. The minimum top diameter of the spruce pulpwood was $7 \mathrm{~cm}$, while the minimum top diameter for the pine pulpwood was $6 \mathrm{~cm}$.

The damage type was considered for all processed stems in the time and motion study (Table 2). The number of stems, processed by damage type, by harvester operator, and by cutting type in the study, is presented in Figure 1. When cutting trees from clear-cutting stands of windfalls, the share of standing trees varied considerably by the harvester operator of the study. On the windfall time-study plots felled by Operator 2, undamaged standing trees and windfalls were not cut separately; rather, the stems were cut in mixed order. Subsequently, the proportion of undamaged standing trees accounted for more than $50 \%$ of the total number of trees (Figure 1). The other operators tended to cut the windfalls first and then the undamaged standing trees. Therefore, there was not a high number of undamaged standing trees in the windthrown clear-cutting stands in these cases.

Table 2. Damage types for all stems processed in the time and motion study.

\begin{tabular}{|c|c|c|}
\hline Code & & Description \\
\hline 0 & $\frac{3}{2}$ & $\begin{array}{l}\text { Standing tree (undamaged standing stem in the } \\
\text { time-study plot). }\end{array}$ \\
\hline $1 \mathrm{~A}$ & Prow & $\begin{array}{l}\text { Uprooted whole tree with stump } \\
\text { (windfall—so-called root ball—tree on the ground; } \\
\text { no separate butt or top sections). }\end{array}$ \\
\hline 1B & & $\begin{array}{l}\text { Hang-up whole tree (standing tree had lodged, } \\
\text { felling a whole stem). }\end{array}$ \\
\hline $1 C$ & & $\begin{array}{l}\text { Uprooted and broken tree with separate butt and top } \\
\text { sections; the butt and top sections of windfalls could } \\
\text { be combined into one stem in the time and } \\
\text { motion study. }\end{array}$ \\
\hline $1 \mathrm{D}$ & & $\begin{array}{l}\text { Broken tree section (broken tree with a separate butt } \\
\text { section or top section; in other words, the butt and } \\
\text { top sections of windfalls could not be combined into } \\
\text { one stem in the time and motion study). }\end{array}$ \\
\hline 2 & 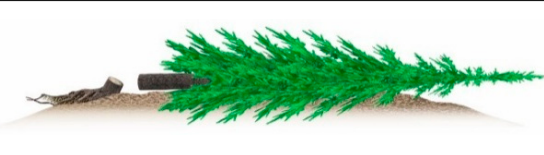 & $\begin{array}{l}\text { Uprooted whole tree without stump (same as the } \\
\text { earlier damage type } 1 \mathrm{~A} \text { but the stump systems of } \\
\text { these uprooted trees had been manually cut by a } \\
\text { forest landowner before salvage cutting). }\end{array}$ \\
\hline
\end{tabular}




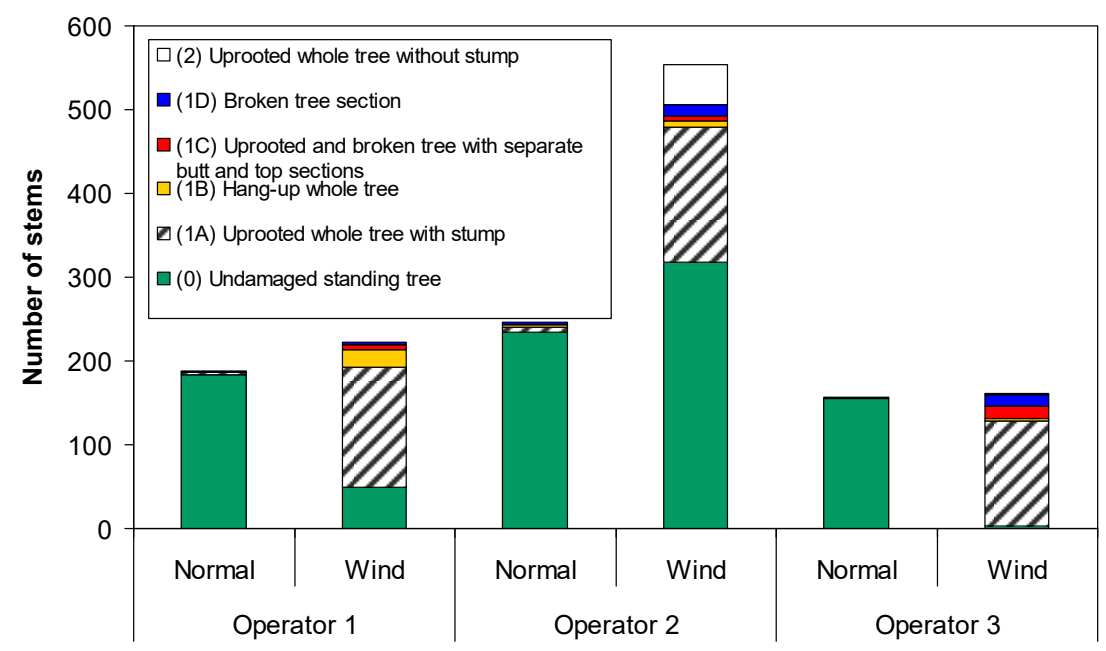

Figure 1. Number of stems $(n=1529)$ by damage type (see Table 2$)$ and by harvester operator for the normal (undamaged standing trees) and windthrown (damaged trees) time-study plots.

In the time and motion study, the work cycle (i.e., all the work elements for processing one stem or one tree section (damage type 1D)) distribution was based on the work cycle distribution used in the time and motion studies by Nuutinen et al. [58] and Palander et al. [59], to which additional work elements relevant to cutting windfalls were added. The work elements are shown in Table A1. Delays in the cutting work (i.e., personal breaks of the operator, repairing or maintenance of the harvester, or harvester relocations from one time-study plot to another) were not considered in the time and motion study.

\subsection{Calculating Operating Hour Costs for Logging Machinery}

The operating hour costs of the logging machines were calculated using the Forest Machine Calculation Program (by Metsäteho Ltd, Vantaa, Finland). The operating costs included both time-dependent and variable operating costs. Cost calculations were prepared for a harvester (weight: 19-21 tonnes; John Deere 1270G, Logset 8H GT and Ponsse Ergo 6w) and a forwarder (carrying capacity: 13-14 tonnes; John Deere 1210G, Logset 6F GT and Ponsse Elk). The cost calculations were drawn up using the following values: The acquisition prices of the harvester and forwarder, based on the prices given by forest machine vendors, were 435,000 and 320,000 $€$ (VAT $0 \%)$, respectively. The depreciation period for the harvester was 6.5 years and for the forwarder was 6.7 years (cf. $[60,61])$. An interest rate of $1.9 \%$ was applied. The productivity per operating hour ( $\mathrm{E}_{15}$, including delays shorter than $15 \mathrm{~min}$ )—also known as the scheduled machine hour (SMH)—of cutting was $27.0 \mathrm{~m}^{3} \mathrm{E}_{15}{ }^{-1}$ (clear cuttings) and $11.0 \mathrm{~m}^{3} \mathrm{E}_{15}{ }^{-1}$ (thinnings) for the harvester (cf. [62]). In forwarding, the corresponding figures were 23.5 and $13.5 \mathrm{~m}^{3} \mathrm{E}_{15}{ }^{-1}$, respectively (cf. [62]).

The proportion of normal standing clear cuttings was $60 \%$ of the total volume of industrial roundwood harvested, and the proportion of normal standing thinnings was $40 \%$. For the harvester and forwarder, the annual industrial roundwood volumes harvested were standardized at $46,000 \mathrm{~m}^{3}$ in the cost calculations. The annual operating hours for the harvester was $2695 \mathrm{E}_{15}$-hours and for the forwarder was $2537 \mathrm{E}_{15}$-hours (cf. [61]). The salary was $16.0 € \mathrm{~h}^{-1}$ for the harvester operator and $15.0 € \mathrm{~h}^{-1}$ for the forwarder operator, with indirect salary costs of $59.0 \%$ added (cf. [63]). The fuel consumptions of the harvester and forwarder were 15.0 and $12.0 \mathrm{dm}^{3} \mathrm{E}_{15}{ }^{-1}$, respectively (cf. [61,64]. Repair and service costs were estimated to be $9.7 € E_{15}{ }^{-1}$ for the harvester and $7.0 € E_{15}{ }^{-1}$ for the forwarder. With the above figures factored in, the calculated operating hour cost for the harvester was $102.6 € \mathrm{E}_{15}{ }^{-1}$ and for the forwarder was $79.5 € \mathrm{E}_{15}{ }^{-1}$ when logging undamaged wood from normal cuttings (Table 3 ). 
Table 3. Annual costs produced by the Forest Machine Calculation Program when calculating the operating hour costs for the harvester and forwarder when logging undamaged timber.

\begin{tabular}{ccc}
\hline Cost Factor & Harvester & Forwarder \\
\hline Time-dependent costs $\left(€ \mathrm{a}^{-1}\right)$ & & 38,722 \\
Depreciation & 67,666 & 3653 \\
Interest & 4916 & 92,188 \\
Labor costs & 107,170 & 2048 \\
Insurance & 3072 & 7,000 \\
Administration & 10,500 & 24,359 \\
Variable costs $\left(€ \mathrm{a}^{-1}\right)$ & 32,339 & 0 \\
Fuel costs & 8190 & 17,762 \\
Guide bar, chain, and chain saw oil costs & 26,141 & 14,034 \\
Repair and service costs & 14,034 & 79.5 \\
Relocation costs & 102.6 & \\
\hline Total operating hour costs $\left(€ \mathrm{E}_{15}{ }^{-1}\right)$ & &
\end{tabular}

In the cost calculations, it was assumed that the calculated operating hour costs $\left(€ E_{15}{ }^{-1}\right)$ of the harvester are $10 \%$ higher for cutting windfalls than for cutting undamaged standing trees. On the contrary, Bergkvist [28] has reported that there is no significant difference between the forwarding productivity of timber in windthrown and normal clear cuttings. When the forwarding unit costs were calculated in the study, the productivity per effective hour ( $\mathrm{E}_{0}$, excluding all delays)—also known as the productive machine hour (PMH) — of forwarding was determined as a function of the stem volume of removal by applying the productivity function of forwarding by Eriksson and Lindroos [62]. The average payload of the forwarder was $14.5 \mathrm{~m}^{3}$ and the average forwarding distance was $300 \mathrm{~m}$ (cf. [65]). The effective $\left(\mathrm{E}_{0}\right)$ hour productivities of cutting (produced by this study) and forwarding (produced by Eriksson and Lindroos [62]) were converted to operating $\left(\mathrm{E}_{15}\right)$ hour productivities by the coefficients of 1.393 and 1.136, respectively (cf. [62,66]). The conversion from the under the bark volumes by Eriksson and Lindroos [62] to the over the bark volumes was conducted by the coefficient of 1.140 (cf. [67]). Finally, the calculated operating hour costs for the harvester were $112.9 € \mathrm{E}_{15}{ }^{-1}$ and for the forwarder were $79.5 € \mathrm{E}_{15}{ }^{-1}$ when logging damaged windthrown timber.

\subsection{Analysis of the Time-Study Data}

The time-study data were initially tested for the normal distribution assumption by a Kolmogorv-Smirnov test. Based on the results of this test, the time consumption data did not comply with a normal distribution. Since the material was not distributed normally, the Mann-Whitney (U) test was applied in the statistical analysis.

For modelling, the time elements were aggregated for the following main time consumption elements of productive cutting work:

- Stem processing time (i.e., boom-out, felling, delimbing \& cross-cutting, and boom-in) ( $\left.\mathrm{y}_{1}\right)$

- Moving time $\left(\mathrm{y}_{2}\right)$, and

- Miscellaneous time (i.e., planning of work, clearing of undergrowth, sorting of industrial roundwood poles, removal of logging residues, removing overlapped and accumulated stems, pulling windfall stems, felling the root system, and shortening the stump) ( $\left.\mathrm{y}_{3}\right)$ (cf. Table A1).

When modelling the moving time and determining the average miscellaneous time consumption per stem, all stems (1529) processed in the study were used. Correspondingly, when calculating the stem processing functions for each operator with windfalls in clear cuts, the damage types 1A-1D and $2(n=572)$ were included in the modelling process. On the contrary, when modelling the stem processing with the undamaged standing trees at clear-cutting sites, only the undamaged standing trees (i.e., damage type 0$)(n=516)$ of the normal clear-cutting plots were utilized. Thus, the final study material for the stem processing analysis was 1088 trees. 
The stem processing time was modelled by applying a non-linear regression analysis with the stem volume $\left(\mathrm{m}^{3}\right)$ and windfall dummy $(0=$ normal clear cutting with an undamaged standing tree (damage type 0); and 1 = wind-damaged tree in a clear-cutting stand (damage types 1A-1D and 2)) as the independent variables. In the study, the density of removal was between $284-708$ stems ha $^{-1}$ (average 422 stems ha $^{-1}$ ) in the clear-cutting plots of windfalls and 367-712 stems ha ${ }^{-1}$ (average 459 stems $\mathrm{ha}^{-1}$ ) in the undamaged clear-cutting plots. Moving time was modelled as a function of the density of removal in the stand.

The total effective times by operator and by cutting type (i.e., normal and windfall clear cutting) were calculated by Equation (1):

$$
\mathrm{T}=\mathrm{y}_{1}+\mathrm{y}_{2}+\mathrm{y}_{3}
$$

where $\mathrm{T}=$ the total effective time consumption of the cutting work $\left(\mathrm{s} \mathrm{stem}^{-1}\right) ; \mathrm{y}_{1}=$ the stem processing time $\left(\mathrm{s} \mathrm{stem}^{-1}\right) ; \mathrm{y}_{2}=$ moving time $\left(\mathrm{s} \mathrm{stem}^{-1}\right) ;$ and $\mathrm{y}_{3}=$ miscellaneous time $\left(\mathrm{s} \mathrm{stem}^{-1}\right)$.

The effective time consumption was converted to effective hour productivity $\left(\mathrm{m}^{3} \mathrm{E}_{0}^{-1}\right)$ by applying Equation (2):

$$
\mathrm{P}=3600 \times\left(\mathrm{x}_{1} / \mathrm{T}\right)
$$

where $\mathrm{P}=$ the effective hour productivity $\left(\mathrm{m}^{3} \mathrm{E}_{0}{ }^{-1}\right) ; \mathrm{x}_{1}=$ stem volume $\left(\mathrm{m}^{3}\right)$; and $\mathrm{T}=$ the total effective time consumption of the cutting work $\left(\mathrm{s} \mathrm{stem}^{-1}\right)$.

Different transformations and curve types were tested in order to achieve symmetrical residuals for the regression models and in order to ensure the statistical significance of the coefficients. All statistical analyses were conducted with IBM SPSS Statistics 21.0 statistical software (https: //www.ibm.com/fi-en/marketplace/spss-statistics).

\section{Results}

\subsection{Time Consumption for Damaged and Undamaged Trees}

\subsubsection{Distribution of Effective Time Consumption}

When cutting undamaged standing trees in clear cuttings, the proportion of time spent on stem processing was, on average, $87.7 \%$ of the total effective time consumption, and the variation by operator ranged from $80.1-91.8 \%$. The share of the moving time was, on average, $9.0 \%$ and varied between $7.1 \%$ and $12.2 \%$ by operator. Miscellaneous time took, on average, $3.3 \%$ of the total time with a variation range of $0.4-7.8 \%$ by operator.

In the clear-cutting stands of wind-damaged trees, the proportion of the stem processing time was $13.4 \%$ lower than that of undamaged standing trees, averaging $74.3 \%$ of the total effective time consumption. Correspondingly, in the windthrown stands, the share of moving time was almost double that of normal clear-cutting stands. The moving time averaged $17.8 \%$ of the total effective time, ranging from $15.2-21.5 \%$ by operator. The proportion of miscellaneous time similarly increased significantly with windfall stems. On average, the share of miscellaneous time was $7.9 \%$ of the total time, and the variation by operator ranged between $3.0-12.2 \%$.

\subsubsection{Distribution of Stem Processing Time}

The processing time (i.e., delimbing and cross-cutting) took most of the total stem processing time. The share of processing time from the total stem processing time was, on average, $61.1 \%$ in the normal clear-cutting stands of undamaged standing trees (Figure 2). At the clear-cutting sites of windfalls, the processing time took, on average, $53.3 \%$ of the total stem processing time.

With all operators, the time element of boom-out-that is, steering out the boom and grabbing-took significantly more of the total stem processing time with windfalls than with the standing stems of normal clear cuts. On average, the boom-out phase took $10.1 \%$ more time with windfalls (26.1\%) than with undamaged standing trees (16.0\%) (Figure 2). On the contrary, felling with 
undamaged standing trees took more time than that with windfalls. The share of the time element of felling was, on average, $21.5 \%$ of the total stem processing time with standing trees while with wind-damaged trees it was $18.2 \%$.

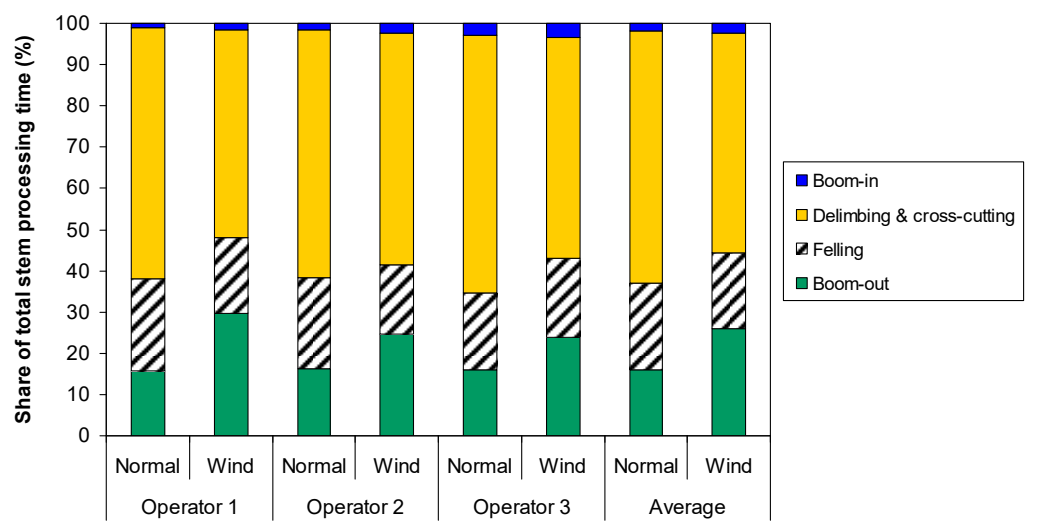

Figure 2. Distributions of total stem processing time by operator and on average in the clear cuttings of normal undamaged standing trees $(n=572)$ and wind-damaged trees $(n=516)$.

\subsubsection{Modelling Stem Processing Time}

The time consumption of stem processing was modelled separately for each operator (Figures 3 and 4, Table 4). When cutting wind-damaged trees, the stem processing time by operator averaged 5.0-14.6 s stem ${ }^{-1}$ longer than that of undamaged standing trees (Figure 4, Table 4). When cutting windfall stems with a volume of $0.3-1.5 \mathrm{~m}^{3}$, the stem processing time increased, on average, 15-37\% compared to cutting undamaged standing trees (Figure 3). For Operator 1, the stem processing time increased the most $(24-57 \%)$ and with Operator 2 the increase was the smallest $(9-21 \%)$ with a stem size of $0.3-1.5 \mathrm{~m}^{3}$ (Figure 3). There were statistically significant differences between undamaged standing and wind-damaged trees in the stem processing times with each operator (Operator 1 : $\mathrm{U}=18,075, p<0.01$; Operator 2: $\mathrm{U}=23,383, p<0.001$; Operator 3: $\mathrm{U}=14,231, p<0.01$ ). The coefficients of determination (adjusted $R^{2}$ ) of the stem processing time consumption models by operator were $64-71 \%$ (Table 4). The residuals of the models were centered on zero and were symmetrical throughout the range of stem volume observations.

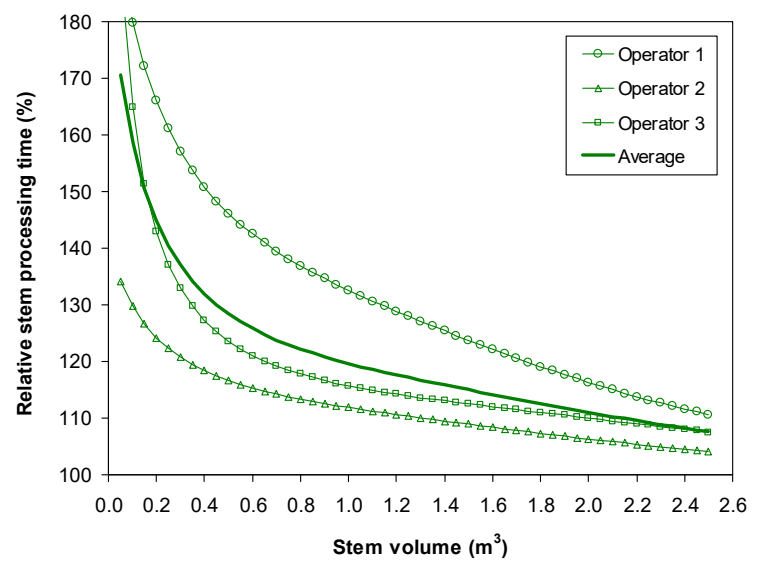

Figure 3. Relative stem processing time in windfall clear cutting by operator and on average as a function of stem volume. Relative stem processing time $100=$ stem processing time in normal clear cutting with undamaged standing trees. 


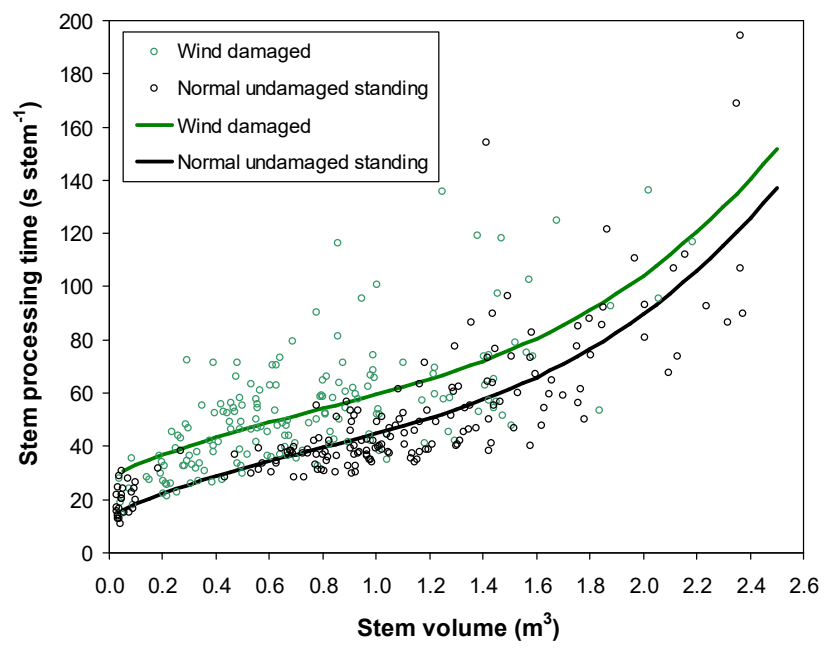

(A)

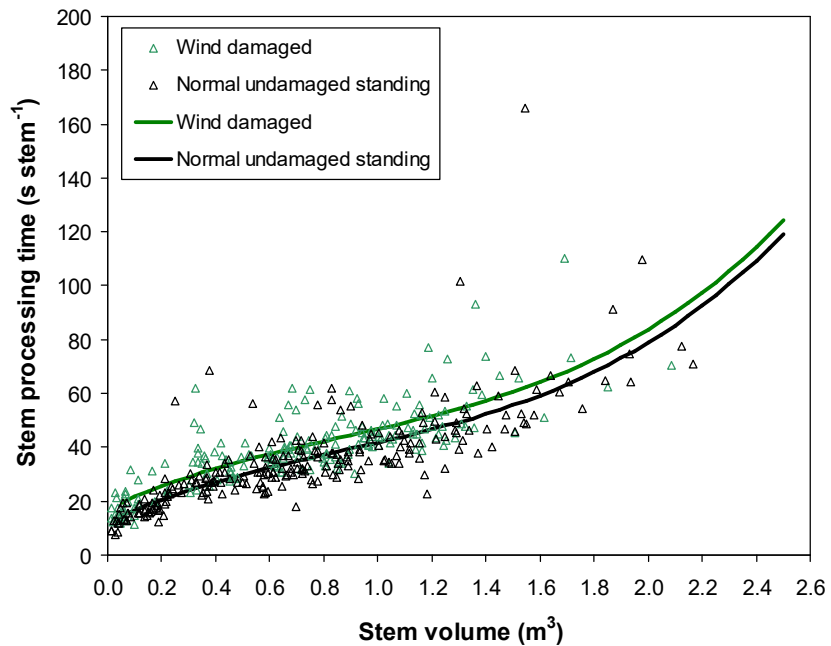

(B)

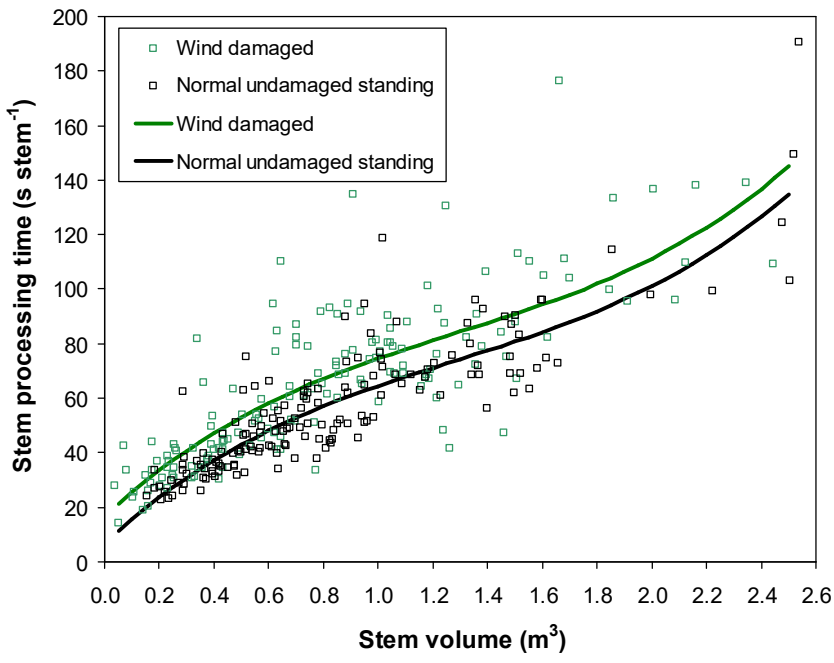

(C)

Figure 4. Stem processing time curves as a function of stem volume by operator with the wind damaged $(n=516)$ and normal undamaged standing $(n=572)$ trees in clear cutting. (A) Operator 1, (B) Operator 2 and (C) Operator 3. 
Table 4. Regression models for the stem processing time consumption by operator in the study.

\begin{tabular}{|c|c|c|c|}
\hline \multicolumn{4}{|c|}{$y_{1}=a+b x_{1}+c x_{1}^{2}+d x_{1}^{3}+e w$} \\
\hline \multicolumn{4}{|c|}{ O1: Adjusted $R^{2}=0.636 ; F$ value $=155^{* * *} ;$ Standard Error of the Estimate of the Model $=15.692$} \\
\hline \multicolumn{4}{|c|}{ O2: Adjusted $R^{2}=0.635 ; F$ value $=184^{* * *} ;$ Standard Error of the Estimate of the Model $=10.259$} \\
\hline \multicolumn{4}{|c|}{ O3: Adjusted $R^{2}=0.709 ; F$ value $=190 * * * ;$ Standard Error of the Estimate of the Model $=14.737$} \\
\hline Operator/Coefficient & Estimate of Coefficient & Standard Error of Estimate & $t$-Value \\
\hline $\mathrm{O} 1 / \mathrm{a}$ & 14.021 & 2.969 & $4.723^{* * *}$ \\
\hline $\mathrm{O} 1 / \mathrm{b}$ & 45.175 & 10.388 & $4.349 * * *$ \\
\hline $\mathrm{O} 1 / \mathrm{c}$ & -24.798 & 10.613 & $-2.336 *$ \\
\hline $\mathrm{O} 1 / \mathrm{d}$ & 10.603 & 2.991 & $3.545^{* * *}$ \\
\hline $\mathrm{O} 1 / \mathrm{e}$ & 14.603 & 1.78 & $8.205^{* * *}$ \\
\hline $\mathrm{O} 2 / \mathrm{a}$ & 12.35 & 1.627 & $7.591^{* * *}$ \\
\hline $\mathrm{O} 2 / \mathrm{b}$ & 46.046 & 7.399 & $6.223^{* * *}$ \\
\hline $\mathrm{O} 2 / \mathrm{c}$ & -26.661 & 9.318 & $-2.861^{* *}$ \\
\hline $\mathrm{O} 2 / \mathrm{d}$ & 10.138 & 3.244 & $3.125^{* *}$ \\
\hline $\mathrm{O} 2 / \mathrm{e}$ & 4.975 & 1.014 & $4.906^{* * *}$ \\
\hline $\mathrm{O} 3 / \mathrm{a}$ & 6.782 & 4.138 & 1.639 \\
\hline $\mathrm{O} 3 / \mathrm{b}$ & 93.455 & 13.673 & $6.835^{* * *}$ \\
\hline $\mathrm{O} 3 / \mathrm{c}$ & -47.707 & 13.155 & $-3.627^{* * *}$ \\
\hline $\mathrm{O} 3 / \mathrm{d}$ & 12.397 & 3.558 & $3.484^{* * *}$ \\
\hline $\mathrm{O} 3 / \mathrm{e}$ & 10.122 & 1.698 & $5.959 * * *$ \\
\hline
\end{tabular}

Note: $\mathrm{y}_{1}=$ stem processing time $\left(\mathrm{s}\right.$ stem $\left.{ }^{-1}\right) ; \mathrm{x}_{1}=$ stem volume $\left(\mathrm{m}^{3}\right) ; \mathrm{a}=$ constant; $\mathrm{b}, \mathrm{c}, \mathrm{d}, \mathrm{e}=$ coefficients of the variables; $\mathrm{w}=$ dummy variable; 1 if wind-damaged stem, 0 when normal undamaged standing stem; $\mathrm{O} 1=\mathrm{Operator}$ $1 ; \mathrm{O} 2=$ Operator $2 ; \mathrm{O} 3=$ Operator $3 ;^{*} p<0.05 ;{ }^{* *} p<0.01 ;{ }^{* * *} p<0.001$.

\subsubsection{Modelling Moving Time and Average Miscellaneous Time}

The moving time per processed stem decreased when the density of removal in the stand increased. When the density of stems processed was 450 stems ha $^{-1}$, the moving time was $11.5 \mathrm{~s} \mathrm{stem}^{-1}$ in the windfall cuttings and $6.5 \mathrm{~s} \mathrm{stem}^{-1}$ in the undamaged standing tree cuttings (Table 5). Consequently, the moving time consumption was $76 \%$ higher for the windfall plots than the non-windfall plots with a density of 450 stems $_{\text {ha }}{ }^{-1}$.

Table 5. Regression model for moving time consumption in the study.

\begin{tabular}{cccc}
\hline \multicolumn{4}{c}{$\mathrm{y}_{\mathbf{2}}=\mathbf{a}+\mathbf{b} / \mathbf{x}_{\mathbf{2}}+\mathbf{c w}$} \\
\hline Adjusted $\boldsymbol{R}^{\mathbf{2}}=\mathbf{0 . 5 5 9} ; \boldsymbol{F}$ value $=\mathbf{9 . 9}{ }^{* *}$; Standard Error of the Estimate of the Model $=\mathbf{2 . 5 3 2}$ \\
\hline Coefficient & Estimate of Coefficient & Standard Error of Estimate & $\boldsymbol{t}$-Value \\
\hline $\mathrm{a}$ & 1.752 & 2.975 & 0.589 \\
$\mathrm{~b}$ & 2138.466 & 1219.316 & 1.762 \\
$\mathrm{c}$ & 4.935 & 1.366 & $3.614^{* *}$ \\
\hline
\end{tabular}

Note: $\mathrm{y}_{2}=$ moving time $\left(\mathrm{s} \mathrm{stem}^{-1}\right) ; \mathrm{x}_{2}=$ density of removal $\left(\right.$ stem ha $\left.{ }^{-1}\right) ; \mathrm{a}=$ constant; $\mathrm{b}, \mathrm{c}=$ coefficients of the variables; $\mathrm{w}=$ dummy variable; 1 if wind-damaged stand, 0 when normal undamaged stand; ${ }^{*} p<0.05 ;{ }^{* *} p<0.01$; *** $p<0.001$.

The miscellaneous time for cutting wind-damaged trees averaged $3.7 \mathrm{~s} \mathrm{stem}{ }^{-1}$ and with undamaged standing trees averaged $1.5 \mathrm{~s} \mathrm{stem}^{-1}$. Hence, the miscellaneous time for cutting windfalls was $147 \%$ higher than that of undamaged standing trees.

\subsection{Cutting Productivity of Damaged and Undamaged Trees}

The total effective time consumption for cutting was, on average, $51.8 \mathrm{~s} \mathrm{stem}^{-1}$ when cutting the wind-damaged stems of $0.3 \mathrm{~m}^{3}$. When the stem size of removal was $1.5 \mathrm{~m}^{3}$, the total effective time 
consumption for cutting windfalls in clear cuts averaged $91.0 \mathrm{~s} \mathrm{stem}^{-1}$. When cutting windthrown stems with a volume of $0.3 \mathrm{~m}^{3}$, the total effective time consumption was $49 \%$ higher than with undamaged standing trees, and with the windfall trees of $1.5 \mathrm{~m}^{3}$, the total effective time consumption was $23 \%$ higher than that of the undamaged standing trees.

The effective hour productivity averaged $20.8 \mathrm{~m}^{3} \mathrm{E}_{0}{ }^{-1}$ when cutting the wind-damaged stems of $0.3 \mathrm{~m}^{3}$ (Figure 5). When the stem size of removal was $1.5 \mathrm{~m}^{3}$, the effective hour productivity for cutting windfalls was, on average, $59.3 \mathrm{~m}^{3} \mathrm{E}_{0}{ }^{-1}$. On average, the cutting productivity of wind-damaged trees was 10.2-13.7 $\mathrm{m}^{3} \mathrm{E}_{0}^{-1}$ lower than that of the undamaged standing trees when the stem volume of removal was $0.3-1.5 \mathrm{~m}^{3}$. Consequently, the cutting productivity of windfalls was, on average, 19-33\% lower than when cutting the undamaged standing trees of clear cuttings with a stem volume of $0.3-1.5 \mathrm{~m}^{3}$ (Figure 6).

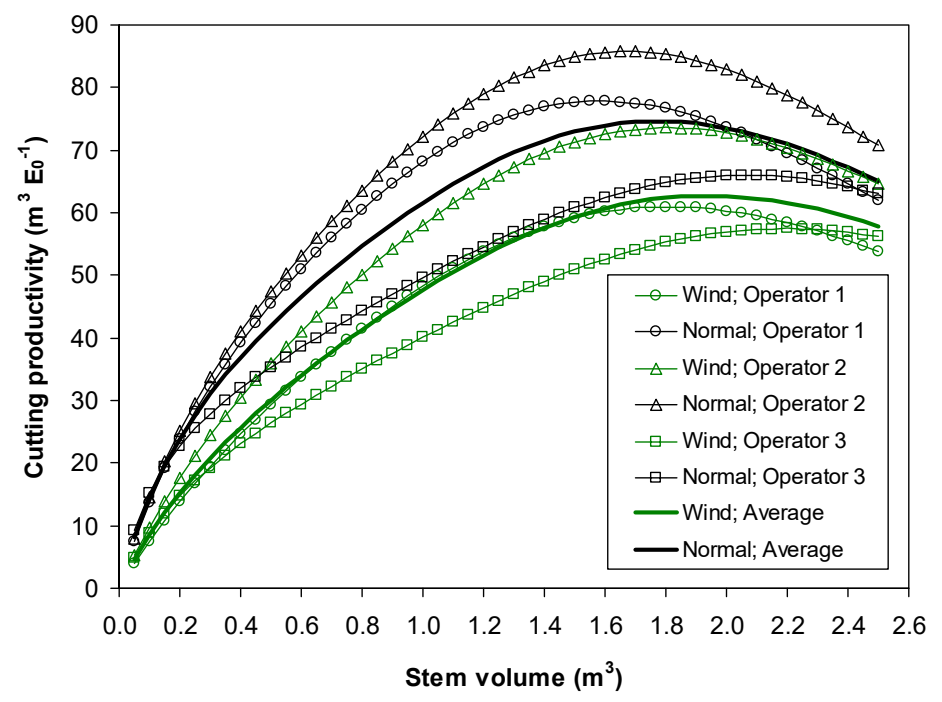

Figure 5. Cutting productivity in clear-cutting stands of wind-damaged and normal undamaged standing trees as a function of stem volume by operator and on average (cf. Table A2). The density of removal was 450 stems $^{-1}$.

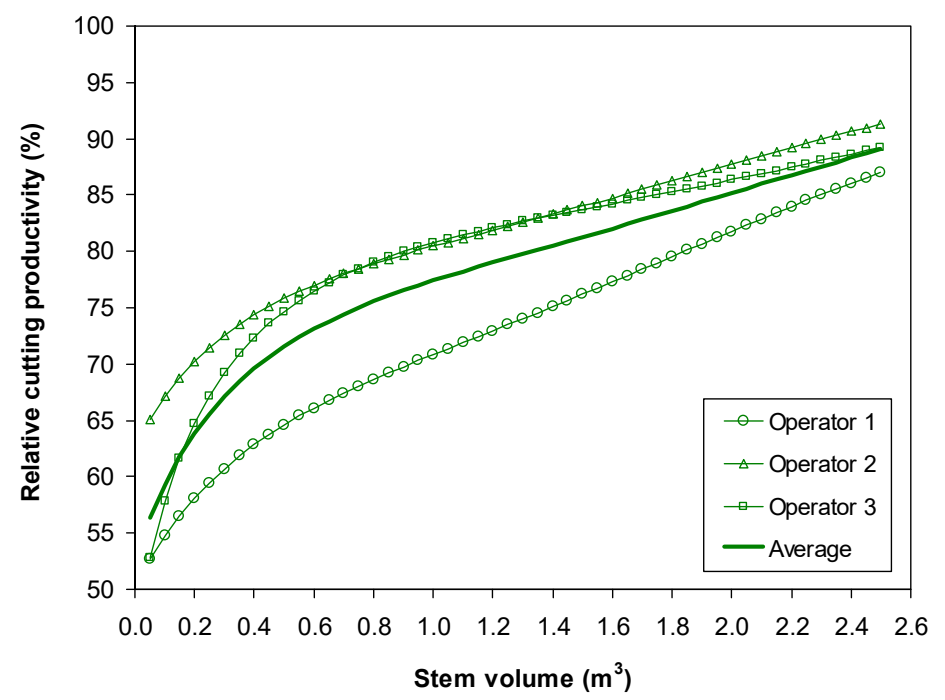

Figure 6. Relative cutting productivity in windfall clear cutting as a function of stem volume by operator and on average. Productivity $100=$ cutting productivity in normal clear cutting with undamaged standing trees. The density of removal was 450 stems ha $^{-1}$. 
The average maximum cutting productivity $\left(74.7 \mathrm{~m}^{3} \mathrm{E}_{0}{ }^{-1}\right)$ was achieved in the clear cuttings of undamaged standing trees when the stem volume was $1.77 \mathrm{~m}^{3}$. Correspondingly, in the windfall clear cuts, the average maximum cutting productivity $\left(62.7 \mathrm{~m}^{3} \mathrm{E}_{0}{ }^{-1}\right)$ was reached when cutting the damaged stems with a volume of $1.94 \mathrm{~m}^{3}$ (Figure 5). After these stem volumes of removal were reached, the average cutting productivities started to decrease. The average productivity functions for cutting wind-damaged and undamaged standing trees are displayed in Table A2.

\subsection{Cutting and Logging Costs of Damaged and Undamaged Trees}

When the stem size of removal was $0.3 \mathrm{~m}^{3}$, the average costs were $7.55 € \mathrm{~m}^{-3}$ when cutting the windfalls of the clear-cutting stands. On the contrary, the costs were, on average, $4.61 € \mathrm{~m}^{-3}$ when cutting the undamaged standing trees of the clear cuttings. Hence, when cutting the wind-damaged stems of $0.3 \mathrm{~m}^{3}$, the cutting costs were $64 \%$ higher than those of the undamaged standing trees (Figure 7A). In cutting the windfall trees of $1.5 \mathrm{~m}^{3}$, the average cutting costs were $2.65 € \mathrm{~m}^{-3}$, and when cutting the undamaged standing stems of $1.5 \mathrm{~m}^{3}$, the average costs were $1.96 € \mathrm{~m}^{-3}$. To sum up, the cutting costs were $35 \%$ higher with windfalls than with the undamaged standing stems of $1.5 \mathrm{~m}^{3}$ (Figure 7A).

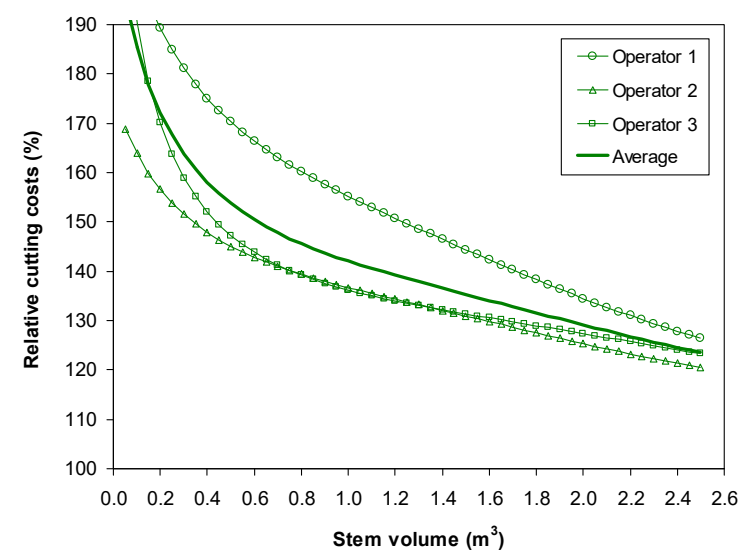

(A)

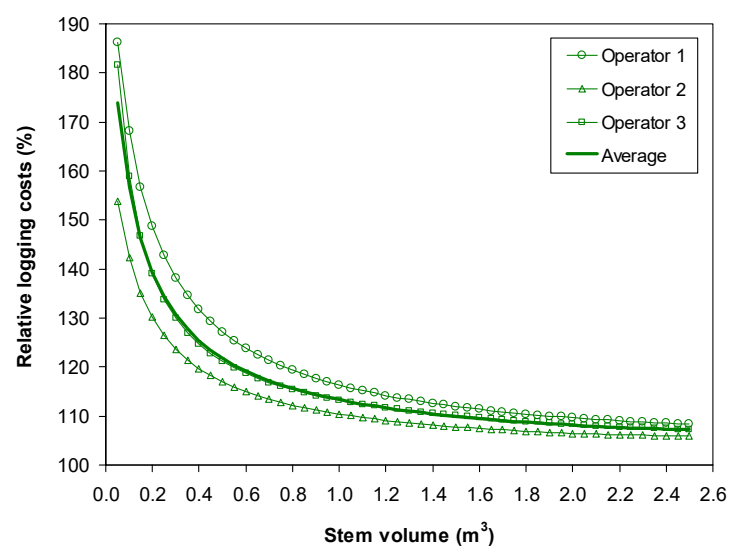

(B)

Figure 7. Relative cutting (A) and logging (B) costs in windfall clear cutting as a function of stem volume by operator and on average. Cost $100=$ cutting/logging costs in normal clear cutting with undamaged standing trees. The density of removal was 450 stems ha $^{-1}$.

With small-sized $\left(0.3 \mathrm{~m}^{3}\right)$ windfalls in clear-cutting stands, the logging costs averaged $12.82 € \mathrm{~m}^{-3}$ and $9.88 € \mathrm{~m}^{-3}$ with the undamaged standing trees. In large-diameter $\left(1.5 \mathrm{~m}^{3}\right)$ clear cuts, the corresponding figures were 7.93 and $7.23 € \mathrm{~m}^{-3}$, respectively. Hence, when logging the windfalls of $0.3 \mathrm{~m}^{3}$, the costs were $30 \%$ higher than those of the undamaged standing trees (Figure 7B). When logging large-sized $\left(1.5 \mathrm{~m}^{3}\right)$ wind-damaged stems in the clear-cutting stands, the logging costs were only $10 \%$ higher than those of the undamaged stems (Figure 7B).

\section{Discussion}

\subsection{Evaluation of Datasets and Approaches}

There were three harvester-operator combinations in the study. All selected harvester operators had experience in cutting windfalls caused by previous catastrophic windstorms-particularly the Asta storm-in the summer and autumn of 2010 in eastern Finland. This was prioritized to make sure that the cutting work of each operator was efficient with the windfalls used in the study (cf. [29,31]). Numerous earlier forest work studies have been carried out to analyze the effect of the harvester operator on performance, and many studies have emphasized that there is a significant correlation 
between the work experience and skills of an operator and his/her productivity in forest machine work (e.g., [68-75]). For instance, Purfürst and Erler [74] have found out that together, the stem volume and the operator explain $84 \%$ of the total overall variation in cutting productivity, and the operator alone explains 37\% of the variance. Previously, Brzózko et al. [29,31] emphasized the effect of a harvester operator on cutting productivity at wind-damaged harvesting sites in Poland. Brzózko et al. [29,31] observed that operators' operational experience under different windthrown harvesting conditions may be the most significant factor affecting cutting productivity.

Data for this study were captured manually by a video camera to record the cutting work in the wind-damaged and undamaged standing tree stands. The time and motion study was conducted by analyzing the video material using the analysis tool, with which a video clip was browsed and the work element boundaries were determined. The record for each work element could be double-checked and edited afterwards using the recorded time signature in the video clip. The analysis tool was applicable and workable. It can be concluded that the data collection method and analysis process used were the only possible data processing procedures that would work for our study where the cutting conditions with windfalls were not normal and the work cycle of the cutting work was unpredictable and complex due to the diversity of damage caused by windstorm in the study stands.

In the study, the total data included 1529 wind-damaged and undamaged standing stems, and the final study material for the modelling of stem processing time was 1088 clear-cutting trees. The size of the study material was relatively large compared to the study material of earlier clear-cutting time studies completed in the 2000s. For example, the clear-cutting data in the study by Nurminen et al. [76] included 636 stems, and the data in the study by Dvořák [30] included 631 processed trees. There are some other larger sets of cutting data of clear cuts but they are mainly long-term follow-up studies, such as the study by Spinelli et al. [77] in which the data included 15,366 trees. Further examples include the research by Gerasimov et al. [78] in which 4.3 million stems were cut, and the research by Eriksson and Lindroos [62] which had a dataset of more than 12,000 clear-cut stands.

The study material consisted mainly of Norway spruce-dominated stands with relatively minor windstorm damage caused by the low-pressure windstorms in autumn and at the end of the year when the ground was not frozen. Windstorm damage for Finnish forests has often occurred in November and December in the 21st century. Gardiner et al. [2] reported that in Europe the most damage to forests is caused by winter storms (occurring from November-January). In our study, there were also only a small number of seriously damaged stems and only a few broken stems (damage types 1C and 1D; 8-20 stems) by harvester operator, respectively. Moreover, the uprooted trees had fallen in parallel arrangements (cf. $[10,11])$ and there was little difficult accumulation of windfall trees. Therefore, the stem processing functions for each damage type by study operator were not modelled. The damage types 1A-1D and 2 were also combined and the stem processing models with all windfalls for each operator conducted. This could be explored in the future with a greater amount of study data.

\subsection{Evaluation of the Main Findings}

This study results revealed that when cutting windfalls in clear cuts, the moving and miscellaneous time spent increases significantly ( $76 \%$ and $157 \%$, respectively) compared to the time required for cutting undamaged standing trees. In the study by Szewczyk et al. [35], in the mature post-disaster stands, the share of moving time averaged 19\% of the total effective time, and it was higher by almost $100 \%$ than in normal stands of undamaged standing trees. The share of moving time was, on average, $18 \%$ of the total effective time consumption in the clear-cutting stands of windfalls in this study. On the other hand, Dvořák [30] reported that the amount of time taken for the harvester to travel into a new position averages $30 \%$ of the total work operation time with windfalls.

Depending on the stem volume $\left(0.3-1.5 \mathrm{~m}^{3}\right)$ of removal in the clear-cutting stand, the average stem processing time of windfalls was $15-37 \%$ higher than that of undamaged standing trees. In particular, the time utilized for steering out the boom and grabbing increased significantly with all harvester operators. On average, the total effective time consumption of cutting with windfalls was $23-49 \%$ 
higher than that of the undamaged standing trees. The results further illustrated that the average effective hour productivity of cutting with windfalls is 19-33\% lower than the cutting of undamaged standing stems in a clear cut. Thus, our research produced new understanding of the effects of windstorm damage on cutting productivity in Finnish coniferous forests.

The earlier salvage logging studies have highlighted that cutting of windfalls takes more time, and cutting productivity is lower than cutting in normal fellings. For instance, Szewczyk et al. [35] reported that the duration of a harvester operation cycle in stands with windbreaks is $28 \%$ longer in mature stands in comparison with normal forest stands. Kim et al. [79] studied the effect of downed trees on harvesting productivity in beetle-killed stands. Their study showed that the productivity of the feller-buncher is significantly affected by the number of downed trees. The feller-buncher's average cycle time was $7.0 \mathrm{~s}$ tree ${ }^{-1}$ when only standing trees were cut and bunched, whereas it took $13.2 \mathrm{~s}^{-1}$ when the bunch included one or more downed trees [79]. Dvořák et al. [37] revealed that the time consumption of cutting with broken stems increases by $7 \%$ compared to cutting of normal stems, and the increase is 33\% during the cutting of fallen trees in Norway spruce stands. Furthermore, Dvořák [30] reported that the productivity of harvesters in salvage felling operations decreases by $11 \%$ upon cutting a stem volume of $0.07 \mathrm{~m}^{3}$ and up to $28 \%$ with a stem volume of $2.2 \mathrm{~m}^{3}$. Brzózko et al. [29] suggested that the cutting productivity at a wind-damaged harvesting site is $40-60 \%$ lower than cutting under similar natural (i.e., normal) conditions.

This study presented new information related to time consumption and productivity of cutting work in Norway spruce-dominated clear cuts of normal standing trees in Finland. The last comprehensive research in this respect in Finland was done over 10 years ago, in 2006 by Nurminen et al. [76]. It can be assumed that during the last ten years, forest machine technology has rapidly progressed, such that modern harvesters are more effective as they are equipped with more powerful booms and hydraulic systems with larger pumps, flows and slewing torques, as well as more accurate control systems and high-quality ergonomics for the harvester operator (cf. Kare [80]). When comparing the cutting productivity of normal standing trees in this study to the cutting productivity of Norway spruce in the study by Nurminen et al. [76], it is noted that the cutting productivity in this study was higher when the stem size of removal was $<0.76 \mathrm{~m}^{3}$ (Figure 8 ), and the opposite was found with larger spruce stems. The cutting productivities reported by Brunberg [81], Jiroušek et al. [82] and Eriksson and Lindroos [62] are also quite close to the average cutting productivity level in the normal clear cuts in this study (Figure 8).

Hence, on the basis of the results of this study, it can be concluded that a big leap has not necessarily been taken in the development of forest machine technology during the last ten years. Nevertheless, when comparing the results of different forest work studies, attention must be paid to the effect of the operator and his/her skills on his/her work performance in cutting operations [68-75]. As the influence of the harvester operator on the cutting productivity in windthrown areas is significant [29,31], it is very important that the skills of operators are superior for the purpose of cutting windfalls safety and effectively. Therefore, effective training and education for cutting windthrown areas for harvester operators at forestry schools is required. Moreover, there is a need for educational video material or guidelines for mechanized cutting in logging operations of windfalls. 


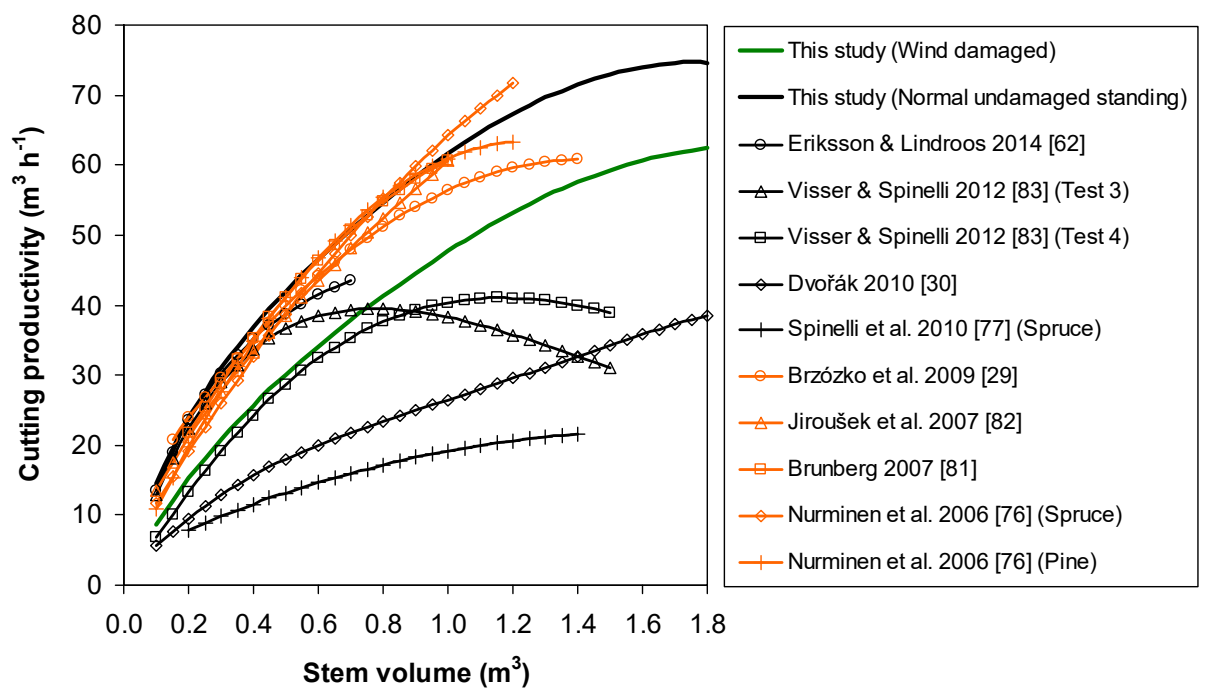

Figure 8. Cutting productivity curves of undamaged standing trees as a function of stem volume presented by some selected studies in the 21st century. All stem volumes and productivities are over bark figures. The productivities by Brunberg [81] and Spinelli et al. [77] are the operating hour productivities $\left(\mathrm{m}^{3} \mathrm{E}_{15}{ }^{-1}\right)$, and the rest of the cutting productivity curves are the effective hour productivities $\left(\mathrm{m}^{3} \mathrm{E}_{0}{ }^{-1}\right)$.

Our study data also included larger-sized (diameter and volume $>1.5 \mathrm{~m}^{3}$ ) trees, in comparison to typical Finnish logging conditions. Thus, the stem processing time consumption functions for larger Norway spruce stems could be modelled, and this enabled the investigation of the development of time consumption functions with larger stems. The stem processing time consumption functions indicated that when the stem size of removal is $>1.5 \mathrm{~m}^{3}$, the time consumption starts to increase (cf. Figure 4). This in turn means that the cutting productivity starts to decrease (cf. Figure 5). These results were interesting because the average peak cutting productivity $\left(75 \mathrm{~m}^{3} \mathrm{E}_{0}{ }^{-1}\right.$-hour) with normal undamaged standing trees was achieved when the stem volume of removal was $1.77 \mathrm{~m}^{3}$ in the clear cut. With windfalls, the peak productivity $\left(63 \mathrm{~m}^{3} \mathrm{E}_{0}{ }^{-1}\right.$-hour $)$ was attained when the stem size was $1.94 \mathrm{~m}^{3}$. When cutting Norway spruce stems of $1.8-1.9 \mathrm{~m}^{3}$ in Finland, the stump diameter $\left(\mathrm{d}_{0}\right)$ is typically around $51-54 \mathrm{~cm}$, the diameter at breast height is $\left(\mathrm{d}_{1.3}\right) 40-43 \mathrm{~cm}$, and the weight is more than $1500-1600 \mathrm{~kg} \mathrm{stem}^{-1}$.

The harvesters used for this study were typical logging machinery for clear cuttings in Finland. Their work weight was around 20 tonnes, the maximum feeding diameter of the harvester head was $62-75 \mathrm{~cm}$, and the maximum delimbing diameter was $43-70 \mathrm{~cm}$ (Table 1). Hence, it is a quite logical that when the stem size was around $1.8-1.9 \mathrm{~m}^{3}$, the cutting productivity with the study harvesters met its high-peak level in these kind of logging conditions. When aiming to increase cutting productivity with a stem volume of more than $1.8 \mathrm{~m}^{3}$ in Finnish coniferous forests, larger-sized harvesters are needed (e.g., John Deere 1470G, Logset 8H GTE, Ponsse Ergo 8w/Scorpion). Visser and Spinelli [83] have also studied the shape of the productivity function for mechanized felling and felling-processing work in New Zealand and Italy. In the Italy tests, the maximum or peak productivity $\left(39-47 \mathrm{~m}^{3} \mathrm{E}_{0}{ }^{-1}\right)$ was achieved when the stem size was $0.7-1.6 \mathrm{~m}^{3}$. Correspondingly, the maximum productivity $\left(252-280 \mathrm{~m}^{3} \mathrm{E}_{0}{ }^{-1}\right)$ was reached with a stem volume of $1.9-2.8 \mathrm{~m}^{3}$ in the New Zealand tests. The different peak performance levels determined by Visser and Spinelli [83] depended significantly on tree volume, the logging machinery used, and the function form applied (quadratic or exponential) in the research.

Forwarding of logs cut was not considered in this study. Bergkvist [28] reported that there is no significant difference between the forwarding productivity of timber in windthrown and normal clear cuts. Consequently, in this study, the productivity functions by Eriksson and Lindroos [62] were 
used to determine the productivity of forwarding in both normal and windthrown stands. The cutting unit costs were calculated to presuppose that the operating hourly costs of the harvester in cutting windfalls are $10 \%$ (i.e., $10.3 € \mathrm{E}_{15}{ }^{-1}$ ) higher than those for undamaged standing trees. The presumption had to be made because there is no accurate information regarding how much higher the operating hour costs of the harvesters are in windthrown forests.

Jaakkola [51] demonstrated that when operating in windthrown stands, the cutting productivity is lower, the harvester and its boom and harvester head are under more stress because of pulling jammed windfalls, and consequently the repair and service costs are higher and the depreciation period of the harvester is likely shorter. Additionally, the consumption and costs of the guide bars and chains are higher when sawing frequently sandy stems and soil while cross-cutting fallen stems from their root system on the ground. The larger the harvester and its boom and harvester head that is utilized in windthrown stands, the easier it is to handle windfalls and the more effective the salvage cutting work is. Therefore, at windthrown cutting sites, it can be recommended to use larger harvesters and harvester heads than those in the normal harvester fleet. In this case, the relative stress for the harvester will be smaller in relation to its engine power and other performance properties.

Jaakkola [51] also revealed that very commonly, the areas of windthrown stands are smaller than those of normal stands, and therefore relocation costs are also higher. On the other hand it must be noted that, when cutting windfalls, the harvesting sites of normal standing trees are often also joined with those of windthrown stands. As stated earlier, when there is no accurate information relating to the operating hourly costs of the harvester in windthrown stands, careful clarification of the cost calculation components is needed in further studies.

When applying the presumption used in the study (i.e., the operating hourly costs of the harvester are $10.3 € \mathrm{E}_{15}{ }^{-1}$ higher for windfall stands), the cutting costs of windfalls with a stem volume of 0.3-1.5 $\mathrm{m}^{3}$ were 35-64\% higher than those of undamaged standing trees in clear cuts. Furthermore, the logging costs of windfalls were 10-30\% higher than those of undamaged stems. Consequently, this study reported lower relative logging costs in windthrown clear-cutting stands than the Trade Association of Finnish Forestry and Earth Moving Contractors, who have reported that the logging costs of windfalls are typically 30-70\% higher than those of normal standing stems (cf. [50]). However, it must be noted that all harvester operators in this study were highly skilled in windthrown cuttings. When the effect of the operator on cutting productivity is significant, especially under challenging harvesting conditions (e.g., $[29,31,69]$ ), it can be assumed that if the harvester operators in the study had less experience in windthrown cuttings, the gap between the wind-damaged and undamaged standing trees in cutting productivity would have been greater.

\section{Conclusions}

Different abiotic and biotic disturbances are expected to occur more frequently in the future under a warming climate. Therefore, we will need resource-efficient methods for salvage logging. In this study, we compared the time consumption, productivity, and costs of cutting between damaged and undamaged trees in clear cuttings. We found that the cutting costs of wind-damaged trees with a stem volume of $0.3-1.5 \mathrm{~m}^{3}$ were $35-64 \%$ higher than those of undamaged standing trees. The logging costs of windfalls were $10-30 \%$ higher than those of undamaged normal stems. The study provided new understanding and knowledge of the productivity and costs of salvage logging operations under Finnish conditions. This information is needed to determine accurate and equitable payments for salvage logging for forest machine contractors. Moreover, even if the logging of windfalls is expensive and laborious, salvage logging operations are important for forest health, as they help to decrease the risks for post-disaster damage outbreaks in coniferous forests, such as those caused by spruce bark beetles. If the amount of wind damage is low, the wood may be left on the forest site. This is also a cost-efficient way to increase dead wood, and thus forest biodiversity values. On the other hand, by considering different abiotic and biotic disturbances of forests in forest management and planning, the risks of damages may also be reduced at least to some degree. In this sense, different decision support 
tools could be useful and could support forest managers and decision makers in managing various risks to forests (see e.g., [84-88]).

Author Contributions: K.K., T.A. and T.P. conceived and designed the experiments; T.A. performed the experiments with the assistance of Y.N.; K.K., T.A. and A.P. together with the assistance of T.P., Y.N. and A.L. analyzed the data; K.K. and A.P. drew up the cost calculations; K.K., T.A., T.P., A.P., A.L., H.P. and Y.N. wrote the paper.

Funding: This study was funded by Stora Enso Wood Supply Finland.

Conflicts of Interest: The authors declare no conflict of interest.

\section{Appendix}

Table A1. Work elements of cutting used in the time and motion studies.

\begin{tabular}{|c|c|}
\hline Work Element & Description \\
\hline Moving & $\begin{array}{l}\text { Moving forward and reversing started when the harvester started to move and } \\
\text { ended when the harvester stopped to perform another task. }\end{array}$ \\
\hline Boom-out & $\begin{array}{l}\text { Steering out the boom and grabbing (i.e., Boom-out) started when the boom } \\
\text { started to swing towards a tree and ended when the harvester head rested on a } \\
\text { tree and the felling cut began. }\end{array}$ \\
\hline Felling & $\begin{array}{l}\text { Felling started when the felling cut-or cross-cutting of the stem from its root } \\
\text { system with windfalls-began and ended when the feeding and delimbing of the } \\
\text { stem started. Felling also included a trimming cut of the butt-end of the stem } \\
\text { when needed (e.g., a crack in the butt-end of the stem). }\end{array}$ \\
\hline Moving & $\begin{array}{l}\text { Moving forward and reversing started when the harvester started to move and } \\
\text { ended when the harvester stopped to perform another task. }\end{array}$ \\
\hline Boom-out & $\begin{array}{l}\text { Steering out the boom and grabbing (i.e., Boom-out) started when the boom } \\
\text { started to swing towards a tree and ended when the harvester head rested on a } \\
\text { tree and the felling cut began. }\end{array}$ \\
\hline Felling & $\begin{array}{l}\text { Felling started when the felling cut-or cross-cutting of the stem from its root } \\
\text { system with windfalls-began and ended when the feeding and delimbing of the } \\
\text { stem started. Felling also included a trimming cut of the butt-end of the stem } \\
\text { when needed (e.g., a crack in the butt-end of the stem). }\end{array}$ \\
\hline Processing & $\begin{array}{l}\text { Processing consisted of delimbing and cross-cutting. Processing started when the } \\
\text { feeding rolls started to run and ended when the last piece of the stem dropped } \\
\text { from the harvester head. }\end{array}$ \\
\hline Boom-in & $\begin{array}{l}\text { Steering the boom front (i.e., Boom-in) occurred when the operator steered the } \\
\text { harvester head to the front of the harvester before moving forward or reversing. }\end{array}$ \\
\hline $\begin{array}{l}\text { Miscellaneous times with normal } \\
\text { standing trees and windfalls }\end{array}$ & $\begin{array}{l}\text { Miscellaneous times in cutting work with normal standing trees and windfalls were: } \\
\text { - } \quad \text { Planning of work } \\
\text { - } \quad \text { Clearing of undergrowth } \\
\text { - } \quad \text { Sorting of industrial roundwood poles } \\
\text { - } \quad \text { Removal of logging residues. }\end{array}$ \\
\hline $\begin{array}{l}\text { Miscellaneous times only } \\
\text { with windfalls }\end{array}$ & $\begin{array}{l}\text { Miscellaneous times only in cutting work with windfalls were: } \\
\text { - Removing overlapped and accumulated stems and transferring the stems so } \\
\text { that they could be processed butt-end first. } \\
\text { Pulling windfall stems which had jammed under the other windfalls. The } \\
\text { work element ended when the stem pulled away and began to } \\
\text { move normally. } \\
\text { Felling the root system. The work element began when the harvester head } \\
\text { started to swing towards an uprooted root system or root ball and ended } \\
\text { when the root system overthrew and the next work element started. } \\
\text { Shortening the stump. The work element began when the harvester head } \\
\text { started to swing towards the stump and ended when the stump had been } \\
\text { sawn and the next work element started. }\end{array}$ \\
\hline
\end{tabular}


Table A2. Average productivity functions for cutting windfalls $\left(\mathrm{P}_{\mathrm{W}}\right)$ and normal $\left(\mathrm{P}_{\mathrm{N}}\right)$ undamaged standing trees in the study. The density of removal was 450 stems ha $^{-1}$.

\begin{tabular}{ccc}
\hline \multicolumn{3}{c}{$\mathbf{P}=\mathbf{a}+\mathbf{b x}_{\mathbf{1}}+\mathbf{c x}_{\mathbf{1}}{ }^{\mathbf{2}}+\mathbf{d x}_{\mathbf{1}}{ }^{\mathbf{3}}+\mathbf{e x}_{\mathbf{1}} \mathbf{4}^{\mathbf{4}}+\mathbf{f x}_{\mathbf{1}}{ }^{\mathbf{5}}+\mathbf{g x}_{\mathbf{1}}{ }^{\mathbf{6}}$} \\
\hline Coefficient & $\mathbf{P}_{\mathbf{W}}$ & $\mathbf{P}_{\mathbf{N}}$ \\
\hline $\mathrm{c}$ & \multicolumn{2}{c}{ Estimate of Coefficient } \\
$\mathrm{b}$ & 0.5781 & 2.4271 \\
$\mathrm{c}$ & 88.316 & 136.65 \\
$\mathrm{~d}$ & -91.344 & -185.86 \\
$\mathrm{e}$ & 86.247 & 190.15 \\
$\mathrm{f}$ & -47.279 & -109.04 \\
$\mathrm{~g}$ & 12.44 & 30.563 \\
& -1.2628 & -3.3340 \\
\hline
\end{tabular}

Note: $\mathrm{P}_{\mathrm{W}}=$ effective hour productivity of wind-damaged trees $\left(\mathrm{m}^{3} \mathrm{E}_{0}{ }^{-1}\right) ; \mathrm{P}_{\mathrm{N}}=$ effective hour productivity of normal undamaged standing trees $\left(\mathrm{m}^{3} \mathrm{E}_{0}^{-1}\right) ; \mathrm{x}_{1}=$ stem volume $\left(\mathrm{m}^{3}\right) ; \mathrm{a}=$ constant; $\mathrm{b}, \mathrm{c}, \mathrm{d}, \mathrm{e}, \mathrm{f}, \mathrm{g}=$ coefficients of the variables.

\section{References}

1. Schelhaas, M.-J.; Nabuurs, G.-J.; Schuck, A. Natural disturbances in the European forests in the 19th and 20th centuries. Glob. Chang. Biol. 2003, 9, 1620-1633. [CrossRef]

2. Gardiner, B.; Blennow, K.; Carnus, J.-M.; Fleischer, P.; Ingemarson, F.; Landmann, G.; Lindner, M.; Marzano, M.; Nicoll, B.; Orazio, C.; et al. Destructive Storms in European Forests: Past and Forthcoming Impacts; Final report to European Commission-DG Environment; European Forestry Institute: Joensuu, Finland, 2010; 138p.

3. Gregow, H. Impacts of Strong Winds, Heavy Snow Loads and Soil Frost Conditions on the Risks to Forests in Northern Europe. Finnish Meteorological Institute Contributions 94, Finnish Meteorological Institute, Helsinki, Finland. Ph.D. (Agr. and For.) Thesis, Faculty of Science and Forestry, School of Forest Sciences, University of Eastern Finland, Joensuu, Finland, 2013; 178p.

4. Schelhaas, M.-J. Impacts of Natural Disturbances on the Development of European Forest Resources: Application of Model Approaches from Tree and Stand Levels to Large-Scale Scenarios. Alterra Scientific Contributions 23, Alterra, Wageningen, The Netherlands. Ph.D. (Agr. and For.) Thesis, Faculty of Forest Sciences, University of Joensuu, Joensuu, Finland, 2008; 168p.

5. Schuck, A.; Schelhaas, M.-J. Storm damage in Europe-An overview. In Living with Storm Damage to Forests; Gardiner, B., Schuck, A., Schelhaas, M.-J., Orazio, C., Blennow, K., Nicoll, B., Eds.; What Science Can Tell Us 3; European Forestry Institute: Joensuu, Finland, 2013; pp. 15-23.

6. Sondell, J. Operation Gudrun: Erfarenheter och förslag till förbättringar (Operation Gudrun: Experiences and Proposals for Improvements); Abetsrapport från Skogforsk 617; Skogforsk: Uppsala, Sweden, 2006; 40p.

7. Ihalainen, A.; Ahola, A. Pyry- ja Janika-myrskyjen aiheuttamat puuston tuhot (Damage caused by the Pyry and Janika windstorms in Finland). Metsätieteen Aikakauskirja 2003, 3, 385-401. [CrossRef]

8. Finnish Forest Research Institute. Asta, Veera, Lahja ja Sylvi Tekivät Pahaa Jälkeä: Metsien Myrskytuhot yli 8 Miljoonaa Kuutiometriä (The Asta, Vera, Lahja and Sylvi Windstorms Caused Catastrophic Damage: More than 8 Million $\mathrm{m} 3$ of Windfall Timber in Finland). Newsletter 21.12.2010. Available online: http: / / www.metla.fi/tiedotteet/2010/2010-12-21-metsien-myrskytuhot.htm (accessed on 3 March 2018).

9. Centre for Economic Development, Transport and the Environment of Southern Savo. Eino-myrskyn tuhot Etelä-Savossa (Damage Caused by the Eino Windstorm in Southern Savo, Finland). ESAELY/759/00.04.00/2013. 2p. Available online: https://www.ely-keskus.fi/documents/10191/ 276041/Eino+myrsky+ESAELYn+vastaus+Mavin+selvityspyynt\%C3\%B6\%C3\%B6n/a8858297-4502-4eccb6c0-8e4b4b44fe19 (accessed on 3 March 2018).

10. Kärhä, K.; Anttonen, T.; Palander, T.; Poikela, A.; Keskinen, S.; Laurén, A.; Nuutinen, Y.; Rajala, P.T. Cutting productivity of windfalls in Finland. In Proceedings of the FORMEC 2015-Forest Engineering: Making a positive contribution, Linz, Austria, 4-8 October 2015; pp. 135-139. 
11. Kärhä, K.; Rajala, P.T.; Anttonen, T.; Palander, T.; Poikela, A.; Keskinen, S.; Laurén, A.; Nuutinen, Y. Myrskytuhopuun Hakkuun Ajanmenekki ja Tuottavuus (Time Consumption and Productivity of Salvage Cutting in Windthrown Stands); Metsätehon Tuloskalvosarja 12; Metsäteho Ltd: Vantaa, Finland, 2015; 27p.

12. Schlyter, P.; Stjernquist, I.; Bärring, L.; Jönsson, A.M.; Nilsson, C. Assessment of the impacts of climate change and weather extremes on boreal forests in northern Europe, focusing on Norway spruce. Clim. Res. 2006, 31, 75-84. [CrossRef]

13. Ulbrich, U.; Pinto, J.G.; Kupfer, H.; Leckebusch, G.C.; Spangehl, T.; Reyers, M. Changing Northern Hemisphere Storm Tracks in an Ensemble of IPCC Climate Change Simulations. J. Clim. 2008, 21, 1669-1679. [CrossRef]

14. Bengtsson, L.; Hodges, K.I.; Keenlyside, N. Will Extratropical Storms Intensify in a Warmer Climate? J. Clim. 2009, 22, 2276-2301. [CrossRef]

15. Leckebusch, G.C.; Koffi, B.; Ulbrich, U.; Pinto, J.G.; Spangehl, T.; Zacharias, S. Analysis of frequency and intensity of European winter storm events from a multi-model perspective, at synoptic and regional scales. Clim. Res. 2006, 31, 59-74. [CrossRef]

16. Nikulin, G.; Kjellström, E.; Hansson, U.; Strandberg, G.; Ullerstig, A. Evaluation and future projections of temperature, precipitation and wind extremes over Europe in an ensemble of regional climate simulations. Tellus 2011, 63A, 41-55. [CrossRef]

17. Pryor, S.C.; Barthelmie, R.J.; Clausen, N.E.; Drews, M.; MacKellar, N.; Kjellström, E. Analyses of possible changes in intense and extreme wind speeds over northern Europe under climate change scenarios. Clim. Dyn. 2012, 38, 189-208. [CrossRef]

18. Peltola, H.; Kellomäki, S.; Väisänen, H. Model Computations on the Impact of Climatic Change on the Windthrow Risk of Trees. Clim. Chang. 1999, 41, 17-36. [CrossRef]

19. Kellomäki, S.; Maajärvi, M.; Strandman, H.; Kilpeläinen, A.; Peltola, H. Model Computations on the Climate Change Effects on Snow Cover, Soil Moisture and Soil Frost in the Boreal Conditions over Finland. Silva Fenn. 2010, 44, 213-233. [CrossRef]

20. Gregow, H.; Peltola, H.; Laapas, M.; Saku, S.; Venäläinen, A. Combined Occurrence of Wind, Snow Loading and Soil Frost with Implications for Risks to Forestry in Finland under the Current and Changing Climatic Conditions. Silva Fenn. 2011, 45, 35-54. [CrossRef]

21. Venäläinen, A.; Laapas, M.; Pirinen, P.; Horttanainen, M.; Hyvönen, R.; Lehtonen, I.; Junila, P.; Hou, M.; Peltola, H.M. Estimation of the high-spatial-resolution variability in extreme wind speeds for forestry applications. Earth Syst. Dyn. 2017, 8, 529-545. [CrossRef]

22. Beniston, M.; Stephenson, D.B.; Christensen, O.B.; Ferro, C.A.T.; Frei, C.; Goyette, S.; Halsnaes, K.; Holt, T.; Jylhä, K.; Koffi, B.; et al. Future extreme events in European climate: an exploration of regional climate model projections. Clim. Chang. 2007, 81, 71-95. [CrossRef]

23. Schelhaas, M.-J.; Hengeveld, G.; Moriondo, M.; Reinds, G.J.; Kundzewicz, Z.W.; ter Maat, H.; Bindi, M. Assessing risk and adaptation options to fires and windstorms in European forestry. Mitig. Adapt. Strateg. Glob. Chang. 2010, 15, 681-701. [CrossRef]

24. Thom, D.; Seidl, R. Natural disturbance impacts on ecosystem services and biodiversity in temperate and boreal forests. Biol. Rev. 2016, 91, 760-781. [CrossRef] [PubMed]

25. Thorn, S.; Bässler, C.; Brandl, R.; Burton, P.J.; Cahall, R.; Campbell, J.L.; Castro, J.; Choi, C.-Y.; Cobb, T.; Donato, D.C.; et al. Impacts of salvage logging on biodiversity: A meta-analysis. J. Appl. Ecol. 2018, 55, 279-289. [CrossRef] [PubMed]

26. Lindenmayer, D. Salvage harvesting-Past lessons and future issues. For. Chron. 2006, 82, 48-53. [CrossRef]

27. Hagauer, D. Mechanisierte Sturmholzaufarbeitung in der Schweiz (Mechanized Wood Harvesting in Windthrown Forests in Switzerland). M.Sc. Thesis, Institut für Alpine Naturgefahren und Forstliches Ingenieurwesen, Universität für Bodenkultur, Vienna, Austria, 2001; 50p.

28. Bergkvist, I. Upparbetning av Stormskadad Skog_Beskrivning och Analys av de Dominerande Maskinsystemen (Salvaging Windfalls - Description and Analysis of Dominant Machine Systems); Arbetsrapport från Skogforsk 598; Skogforsk: Uppsala, Sweden, 2005; 15p.

29. Brzózko, J.; Szereszewiec, B.; Szereszewiec, E. Productivity of machine timber harvesting at the wind-damaged site. Ann. Warsaw Univ. Life Sci. SGGW Agric. 2009, 54, 41-49.

30. Dvořák, J. Operation time consumption of high-powered harvester in salvage felling. Electr. J. Pol. Agricult. Univ. 2010, 13, 1-12. 
31. Brzózko, J.; Zychowicz, W.; Bartosiewicz, M. The Influence of Operator Experience on Productivity of Mechanized Timber Harvesting From Windfall Stands. In Proceedings of the 45th International Symposium on Forestry Mechanisation: “Forest Engineering: Concern, Knowledge and Accountability in Today's Enviroment", Dubrovnik, Croatia, 8-12 October 2012.

32. Borz, S.A.; Dinulică, F.; Bîrda, M.; Ignea, G.; Ciobanu, V.D.; Popa, B. Time consumption and productivity of skidding Silver fir (Abies alba Mill.) round wood in reduced accessibility conditions: A case study in windthrow salvage logging form Romanian Carpathians. Ann. For. Res. 2013, 56, 363-375.

33. Magagnotti, N.; Picchi, G.; Spinelli, R. A versatile machine system for salvaging small-scale forest windthrow. Biosyst. Eng. 2013, 115, 381-388. [CrossRef]

34. Borz, S.A.; Ignea, G.; Popa, B. Modelling and comparing timber winching performance in windthrow and uniform selective cuttings for two Romanian skidders. J. For. Res. 2014, 19, 473-482. [CrossRef]

35. Szewczyk, G.; Sowa, J.M.; Grzebieniowski, W.; Kormanek, M.; Kulak, D.; Stańczykiewicz, A. Sequencing of harvester work during standard cuttings and in areas with windbreaks. Silva Fenn. 2014, 48, 1159. [CrossRef]

36. Talbot, B.; Pierzchala, M.; Stampfer, K. Operational planning and performance of windfall salvaging in Norway. In Proceedings of the Nordic Baltic Conference OSCAR14, Solutions for Sustainable Forestry Operations, NOVA Park Conference, Knivsta, Sweden, 25-27 June 2014; Björheden, R., Ed.; Arbetsrapport från Skogforsk 830. Skogforsk: Uppsala, Sweden, 2014; pp. 102-103.

37. Dvořák, J.; Walczyk, J.; Natov, P.; Hošková, P. Struktura czasu pracy harwesterów podczas pozyskania przygodnego (Structure of the operating time of the harvesters during casual logging). Sylwan 2015, 159, 300-306.

38. Stempski, W.; Jabłoński, K. Efektywność maszynowego pozyskiwania drewna z drzewostanu uszkodzonego przez wiatr (Effectiveness of mechanized wood harvesting in a tree stand damaged by wind). Nauka Przyr. Technol. 2015, 9, 40. [CrossRef]

39. Nikolov, C.; Konôpka, B.; Kajba, M.; Galko, J.; Kunca, S.; Janský, L. Post-disaster Forest Management and Bark Beetle Outbreak in Tatra National Park, Slovakia. Mount. Res. Dev. 2014, 34, 326-335. [CrossRef]

40. Havašová, M.; Ferenčík, J.; Jakuš, R. Interactions between windthrow, bark beetles and forest management in the Tatra national parks. For. Ecol. Manag. 2017, 391, 349-361. [CrossRef]

41. Lindenmayer, D.B.; Foster, D.R.; Franklin, J.F.; Hunter, M.L.; Noss, R.F.; Schmiegelow, F.A.; Perry, D. Salvage Harvesting Policies After Natural Disturbance. Science 2004, 303, 1303. [CrossRef] [PubMed]

42. Schroeder, L.M. Tree mortality by the bark beetle Ips typographus (L.) in storm-disturbed stands. Integr. Pest Manag. Rev. 2003, 6, 169-175. [CrossRef]

43. Wermelinger, B. Ecology and management of the spruce bark beetle Ips typographus-A review of recent research. For. Ecol. Manag. 2004, 202, 67-82. [CrossRef]

44. Eriksson, M.; Neuvonen, S.; Roininen, H. Retention of wind-felled trees and the risk of consequential tree mortality by the European spruce bark beetle Ips typographus in Finland. Scand. J. For. Res. 2007, 22, 516-523. [CrossRef]

45. Viiri, H.; Ahola, A.; Ihalainen, A.; Korhonen, K.T.; Muinonen, E.; Parikka, H.; Pitkänen, J. Kesän 2010 myrskytuhot ja niistä seuraava hyönteistuhoriski (Windstorm damage of summer 2010 and the risk of insect damage due to the storm). Metsätieteen Aikakauskirja 2011, 3, 221-225. [CrossRef]

46. Stadelmann, G.; Bugmann, H.; Meier, F.; Wermelinger, B.; Bigler, C. Effects of salvage logging and sanitation felling on bark beetle (Ips typographus L.) infestations. For. Ecol. Manag. 2013, 305, 273-281. [CrossRef]

47. Økland, B.; Nikolov, C.; Krokene, P.; Vakula, J. Transition from windfall- to patch-driven outbreak dynamics of the spruce bark beetle Ips typographus. For. Ecol. Manag. 2016, 363, 63-73. [CrossRef]

48. Marini, L.; Økland, B.; Jönsson, A.M.; Bentz, B.; Carroll, A.; Forster, B.; Grégoire, J.-C.; Hurling, R.; Nageleisen, L.M.; Netherer, S.; et al. Climate drivers of bark beetle outbreak dynamics in Norway spruce forests. Ecography 2017, 40, 1-10. [CrossRef]

49. Laki Metsätuhojen Torjunnasta (Forest Damage Prevention Act in Finland) 1087/2013. Available online: http:/ / www.finlex.fi/en/laki/kaannokset/2013/en20131087.pdf (accessed on 3 March 2018).

50. Jaakkola, S.; Myrskytuhojen Korjuu on Kallista (Windthrown Salvage Logging is Expensive). Trade Association of Finnish Forestry and Earth Moving Contractors, Newsletter 3.1.2012. Available online: http: / / www.koneyrittajat.fi/ ?action=news\&news_id=2762012a (accessed on 28 June 2015).

51. Jaakkola, S. Myrskypuiden korjuu ei kannata Suomessa (Windthrown salvaging is not a good business in Finland). Koneyrittäjä 2012, 4, 14-15. 
52. Harstela, P. Work Studies in Forestry; Silva Carelica 18; University of Joensuu: Joensuu, Finland, 1991; 41p.

53. Groover, M.P. Work Systems and Methods, Measurement, and Management of Work; Pearson Education International: Upper Saddle River, NJ, USA, 2007; 778p, ISBN 0-13-135569-4.

54. Skogforsk. Standard for Forest Data and Communications. StanForD, 2007. Available online: http: / / www.skogforsk.se/contentassets/b063db555a664ff8b515ce121f4a42d1/stanford_main-doc_070327.pdf (accessed on 3 March 2018).

55. Niemistö, P.; Korpunen, H.; Laurén, A.; Salomäki, M.; Uusitalo, J. Impact and Productivity of Harvesting while Retaining Young Understorey Spruces in Final Cutting of Downy Birch. Silva Fenn. 2012, 46, 81-97. [CrossRef]

56. Nieuwenhuis, M.; O'Connor, E. Financial impact evaluation of catastrophic storm damage in Irish forestry: A case study. I. Stumpage losses. Forestry 2001, 74, 369-381. [CrossRef]

57. Nieuwenhuis, M.; Fitzpatrick, P.J. An assessment of stem breakage and the reduction in timber volume and value recovery resulting from a catastrophic storm: An Irish case study. Forestry 2002, 75, 513-523. [CrossRef]

58. Nuutinen, Y.; Väätäinen, K.; Heinonen, J.; Asikainen, A.; Röser, D. The Accuracy of Manually Recorded Time Study Data for Harvester Operation Shown via Simulator Screen. Silva Fenn. 2008, 42, 63-72. [CrossRef]

59. Palander, T.; Nuutinen, Y.; Kariniemi, A.; Väätäinen, K. Automatic Time Study Method for Recording Work Phase Times of Timber Harvesting. For. Sci. 2013, 59, 472-483. [CrossRef]

60. Malinen, J.; Laitila, J.; Väätäinen, K.; Viitamäki, K. Variation in age, annual usage and resale price of cut-to-length machinery in different regions of Europe. Int. J. For. Eng. 2016, 27, 95-102. [CrossRef]

61. Statistics Finland. Metsäalan Kone- ja Autokustannusindeksi 2015 = 100 (Machine and Truck Cost Index in Forestry, 2015 = 100); Handbook; Statistics Finland: Helsinki, Finland, 2018; 29p.

62. Eriksson, M.; Lindroos, O. Productivity of harvesters and forwarders in CTL operations in northern Sweden based on large follow-up datasets. Int. J. For. Eng. 2014, 25, 179-200. [CrossRef]

63. Puuliitto. Faktaa Metsäkonealan Työehdoista 1.2.2017-31.1.2018 (Facts about Terms of Employment in Forest Machine Sector, 1.2.2017-31.1.2018). Available online: https:/ / www.teollisuusliitto.fi/wp-content/uploads / 2017/12/Metsakoneala_palkkaohje_2017.pdf (accessed on 30 April 2018).

64. Brunberg, T. Fuel Consumption in Forest Machines 2012; Arbetsrapport Från Skogforsk 789; Skogforsk: Uppsala, Sweden, 2013; 12p.

65. Strandström, M. Average Logging Conditions in Finland, 2010-2016; Metsäteho Ltd, Statistics: Vantaa, Finland, 2017.

66. Kärhä, K.; Poikela, A.; Palander, T. Productivity and Costs of Harwarder Systems in Industrial Roundwood Thinnings. Croat. J. For. Eng. 2018, 39, 23-33.

67. Hakkila, P.; Saranpää, P.; Kalaja, H.; Repola, J. Suomalainen Havukuitupuu-Laadun Hallinta ja Vaihtelu (Finnish Softwood Pulpwood—Quality Management and Variation); Finnish Forest Research Institute: Vantaa, Finland, 2002; 92p.

68. Sirén, M. One-Grip Harvester Operation, It's Silvicultural Result and Possibilities to Predict Tree Damage. Finnish Forest Research Institute Research Papers 694, Finnish Forest Research Institute, Vantaa, Helsinki. Ph.D. (Agr. and For.) Thesis, University of Helsinki, Helsinki, Finland, 1998; 179p.

69. Kärhä, K.; Rönkkö, E.; Gumse, S.-I. Productivity and Cutting Costs of Thinning Harvesters. Int. J. For. Eng. 2004, 15, 43-56.

70. Ovaskainen, H.; Uusitalo, J.; Väätäinen, K. Characteristics and significance of harvester operators' working technique in thinnings. Int. J. For. Eng. 2004, 15, 67-77.

71. Dvořák, J.; Malkovský, Z.; Macků, J. Influence of human factor on the time of work stages of harvesters and crane-equipped forwarders. J. For. Sci. 2008, 54, 24-30. [CrossRef]

72. Ovaskainen, H. Timber Harvester Operators' Working Technique in First Thinning and the Importance of Cognitive Abilities on Work Productivity. Dissertationes Forestales 79. Ph.D. (Agr. and For.) Thesis, Faculty of Forest Sciences, University of Joensuu, Joensuu, Finland, 2009; 62p.

73. Purfürst, F.T. Learning Curves of Harvester Operators. Croat. J. For. Eng. 2010, 31, 89-97.

74. Purfürst, F.T.; Erler, J. The Human Influence on Productivity in Harvester Operations. Int. J. For. Eng. 2011, 22, 15-22.

75. Palander, T.; Ovaskainen, H.; Tikkanen, L. An Adaptive Work Study Method for Identifying the Human Factors that Influence the Performance of a Human-Machine System. For. Sci. 2012, 58, 377-389. [CrossRef] 
76. Nurminen, T.; Korpunen, H.; Uusitalo, J. Time Consumption Analysis of the Mechanized Cut-to-length Harvesting System. Silva Fenn. 2006, 40, 335-363. [CrossRef]

77. Spinelli, R.; Hartsough, B.R.; Magagnotti, N. Productivity Standards for Harvesters and Processors in Italy. For. Prod. J. 2010, 60, 226-235. [CrossRef]

78. Gerasimov, Y.; Senkin, V.; Väätäinen, K. Productivity of single-grip harvesters in clear-cutting operations in the northern European part of Russia. Eur. J. For. Res. 2012, 131, 647-654. [CrossRef]

79. Kim, Y.; Chung, W.; Han, H.; Anderson, N.M. Effect of Downed Trees on Harvesting Productivity and Costs in Beetle-Killed Stands. For. Sci. 2017, 63, 596-605. [CrossRef]

80. Kare, E. Puunkorjuun Koneistuminen-Kehityspolku (Mechanization of Wood Harvesting-Development Pathway); Tekesin Katsaus 304; National Technology Agency (Tekes): Helsinki, Finland, 2015; 47p.

81. Brunberg, T. Basic Data for Productivity Norms for Extra Large Single-Grip Harvesters in Final Felling; Redogörelse från Skogforsk 2; Gälve Offset AB: Gävle, Sweden, 2007; 8p.

82. Jiroušek, R.; Klvač, R.; Skoupý, A. Productivity and costs of the mechanized cut-to-length wood harvesting system in clear-felling operations. J. For. Sci. 2007, 53, 476-482. [CrossRef]

83. Visser, R.; Spinelli, R. Determining the shape of the productivity function for mechanized felling and felling-processing. J. For. Res. 2012, 17, 397-402. [CrossRef]

84. Peltola, H.; Kellomäki, S.; Väisänen, H.; Ikonen, V.-P. A mechanistic model for assessing the risk of wind and snow damage to single trees and stands of Scots pine, Norway spruce, and birch. Can. J. For. Res. 1999, 29, 647-661. [CrossRef]

85. Zeng, H.; Talkkari, A.; Peltola, H.; Kellomäki, S. A GIS-based decision support system for risk assessment of wind damage in forest management. Environ. Model. Softw. 2007, 22, 1240-1249. [CrossRef]

86. Gardiner, B.; Byrne, K.; Hale, S.; Kamimura, K.; Mitchell, S.J.; Peltola, H.; Ruel, J.-C. A review of mechanistic modelling of wind damage risk to forests. Forestry 2008, 81, 447-463. [CrossRef]

87. Honkaniemi, J. Integrating Mechanistic Disturbance Models and Stand Dynamics of Norway Spruce. Dissertationes Forestales 241. Ph.D. (Agr. and For.) Thesis, Department of Forest Sciences, Faculty of Agriculture and Forestry, University of Helsinki, Helsinki, Finland, 2017; 41p.

88. Zubizarreta-Gerendiain, A.; Pukkala, T.; Peltola, H. Effects of wind damage on the optimal management of boreal forests under current and changing climatic conditions. Can. J. For. Res. 2017, 47, 246-256. [CrossRef] 